\title{
Chemistry of $\mathrm{K}$ in $\mathrm{Cu}(\mathrm{In}, \mathrm{Ga}) \mathrm{Se}_{2}$ photovoltaic absorbers: effects of
}

\section{temperature on $\mathrm{Cu}-\mathrm{K}$-In-Se films}

Christopher P. Muzzillo, ${ }^{1,2}$ Ho Ming Tong, ${ }^{2,3}$ and Tim Anderson ${ }^{2}$

${ }^{1}$ National Renewable Energy Laboratory, Golden, CO 80401, USA

${ }^{2}$ Department of Chemical Engineering, University of Florida, Gainesville, FL 32611, USA

${ }^{3}$ Oak Ridge National Laboratory, Oak Ridge, TN 37831, USA

\begin{abstract}
Incorporation of $\mathrm{K}$ has led to world record $\mathrm{Cu}(\mathrm{In}, \mathrm{Ga}) \mathrm{Se}_{2}$ photovoltaic power conversion efficiencies, but there is poor consensus about the role of phase impurities in these advances. This work lays a foundation for identifying and controlling these phase impurities. Films of $\mathrm{Cu}$ K-In-Se were co-evaporated at varied $\mathrm{K} /(\mathrm{K}+\mathrm{Cu})$ compositions and substrate temperatures (with constant $(\mathrm{K}+\mathrm{Cu}) / \mathrm{In} \sim 0.85)$. Increased $\mathrm{Na}$ composition on the substrate's surface and decreased growth temperature were both found to favor $\mathrm{Cu}_{1-\mathrm{x}} \mathrm{K}_{\mathrm{x}} \mathrm{InSe}_{2}$ alloy formation, relative to two-phase $\mathrm{CuInSe}_{2}+\mathrm{KInSe}_{2}$ formation. Structures from X-ray diffraction (XRD), band gaps, resistivities, minority carrier lifetimes and carrier concentrations from time-resolved photoluminescence were in agreement with previous reports, where low $\mathrm{K} /(\mathrm{K}+\mathrm{Cu})$ composition films exhibited properties promising for photovoltaic absorbers. Films grown at $400-500^{\circ} \mathrm{C}$ were then annealed to $600^{\circ} \mathrm{C}$ in a controlled Se ambient, which caused $\mathrm{K}$ loss by evaporation in proportion to the initial $\mathrm{K} /(\mathrm{K}+\mathrm{Cu})$ composition. Similar to growth temperature, annealing drove $\mathrm{Cu}_{1-\mathrm{x}} \mathrm{K}_{\mathrm{x}} \mathrm{InSe}_{2}$ alloy consumption and $\mathrm{CuInSe}_{2}+\mathrm{KInSe}_{2}$ production, as evidenced by high temperature XRD. Annealing also decomposed $\mathrm{KInSe}_{2}$ and formed $\mathrm{K}_{2} \mathrm{In}_{12} \mathrm{Se}_{19}$. At high temperature, the $\mathrm{KInSe}_{2}$
\end{abstract}


crystal lattice gradually contracted as temperature and time increased, as well as just time. Evaporative loss of $\mathrm{K}$ during annealing could accompany the generation of vacancies on $\mathrm{K}$ lattice sites, and may explain the $\mathrm{KInSe}_{2}$ lattice contraction. This knowledge of $\mathrm{Cu}-\mathrm{K}-\mathrm{In}-\mathrm{Se}$ material chemistry may be used to predict and control minor phase impurities in $\mathrm{Cu}(\mathrm{In}, \mathrm{Ga})(\mathrm{Se}, \mathrm{S})_{2}$ photovoltaic absorbers - where impurities below typical detection limits may have played a role in recent world record photovoltaic efficiencies that utilized KF postdeposition treatments.

Graphical abstract:

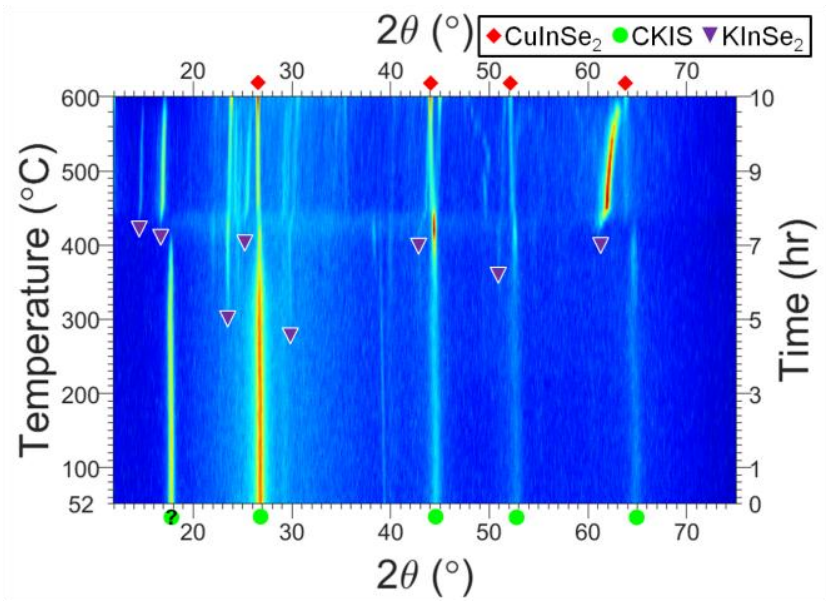


Keywords: Photovoltaics; Solar cells; Semiconductors; Phase transformation; Thin films; Physical vapor deposition

\section{Introduction}

Recent reports have detailed power conversion efficiency enhancement when potassium fluoride and selenium have been co-evaporated onto $\mathrm{Cu}(\mathrm{In}, \mathrm{Ga})(\mathrm{Se}, \mathrm{S})_{2}$ (CIGS) absorbers at around $350^{\circ} \mathrm{C}(\mathrm{KF}$ post-deposition treatment (PDT)) [1-25]. In particular, 6 of the last 8 world record CIGS efficiencies have employed a KF PDT [1, 3, 4, 11, 26, 27], ultimately advancing the record efficiency from 20.3 to $22.6 \%$ in under 4 yr. KF PDT successes in the laboratory have now been extended to commercially-relevant chalcogenized $\mathrm{Cu}(\mathrm{In}, \mathrm{Ga})(\mathrm{Se}, \mathrm{S})_{2}$ absorbers [11], full size $\left(0.75 \mathrm{~m}^{2}\right)$ modules [12], and $\mathrm{Cd}$-free $\mathrm{Zn}(\mathrm{O}, \mathrm{S})$ buffers $[2,11,16,28]$. Although the mechanisms responsible for these efficiency improvements are not clear, the KF PDT has been associated with many phenomena. As example this treatment is reported by several researchers to increase hole concentration $[5-7,10,13-19,29-31]$ by consuming $\operatorname{In}_{\mathrm{Cu}}$ compensating donors to produce $\mathrm{K}_{\mathrm{Cu}}$ neutral defects [32], but in contrast, other researchers have indicated decreased hole concentration via reduction of $\mathrm{Na}_{\mathrm{Cu}}$, which produces $\operatorname{In}_{\mathrm{Cu}}$ compensating donors $[1,7,9,20,33]$. Other examples of the effect of KF PDTs include $\mathrm{Na}$ depletion or formation of soluble $\mathrm{Na}$ compounds $[1,5-7,9,10,12,13,17,21-23,30,34,35]$, Ga depletion at the top surface $[1,7,9$, $12-14,21,22,24,34,36-38], \mathrm{Cu}$ depletion at the top surface $[6,12,14,24,25,39]$ resulting in better near-surface inversion $[1,7,9,20,40]$ or decreased valence band energy [13, 19-21, 24, $29,36,38,41]$, grain boundary passivation [5, 11, 42], general defect passivation $[2,3,10,11]$, minority carrier lifetime enhancement [8, 14, 17-19], morphology changes resulting in increased $\mathrm{CdS}$ nucleation sites $[2,9,43]$ as well as general changes in CdS growth $[13,19,21,36,39,40$, 44], formation of a passivating K-In-Ga-Se [9, 45] or K-In-Se [13, 19, 21, 36-38, 44] interfacial 
compound, formation of a current blocking interfacial compound [30, 46], formation of elemental Se at the surface $[13,37]$, formation of surface $\mathrm{Cu}_{2-\mathrm{x}} \mathrm{Se}$ and $\mathrm{GaF}_{3}$ [13], consumption of a surface 'ordered vacancy compound' [13], and decreased trap concentration [34]. Substrate surfaces with high $\mathrm{K}$ content also led to increased carrier concentrations [15, 32, 47] and modified Cu-Ga-In interdiffusion [15, 47, 48]. Lepetit et al. co-evaporated KF, In, and Se onto CIGS, forming either $\mathrm{KInSe}_{2}$ or K-doped amorphous $\mathrm{In}_{2} \mathrm{Se}_{3}$, and achieved results similar to a $\mathrm{KF}$ PDT [37]. A PDT without KF (just Se) has also been shown to significantly alter CIGS absorber properties [49, 50], confounding the conclusions of KF PDT comparisons. High absorber Na and $\mathrm{K}$ composition has also been linked to accelerated degradation in photovoltaic (PV) performance [51], which may undermine the relevance of initial performance gains achieved with high $\mathrm{Na}$ and $\mathrm{K}$ levels. Specifically, $\mathrm{Na}$ and $\mathrm{K}$ diffused into and degraded the $\mathrm{ZnO}$ layer after $100 \mathrm{~h}$ in damp heat and light [51]. This result underscores the importance of understanding the materials chemistry of alkali metal bonding in CIGS and contacting materials.

While the detailed mechanisms underlying the observed effects of KF PDTs remain uncertain, it has been established that a significant amount of $\mathrm{K}$ segregates at the heterojunction in the most efficient solar cells [1]. These advances have heightened interest in $\mathrm{Cu}-\mathrm{K}-\mathrm{In}-\mathrm{Se}$ material with $\mathrm{K}$-rich $(\mathrm{K} /(\mathrm{K}+\mathrm{Cu})>0.30)$ and group I-poor compositions (i.e. $(\mathrm{K}+\mathrm{Cu}) / \mathrm{In} \sim 0.85$, which avoids $\mathrm{Cu}_{2} \mathrm{Se}$ ). In a departure from work utilizing $\mathrm{KF}$ precursors and PDTs, $\mathrm{Cu}, \mathrm{KF}$, In, and Se were co-evaporated to form $\mathrm{Cu}_{1-\mathrm{x}} \mathrm{K}_{\mathrm{x}} \mathrm{InSe}_{2}$ (CKIS) alloys with $\mathrm{x}=\mathrm{K} /(\mathrm{K}+\mathrm{Cu})$ varied from 0 to $1[35,52,53]$. Increasing $\mathrm{x}$ in CKIS was found to monotonically decrease the chalcopyrite lattice parameter, increase the band gap, and increase the apparent carrier concentration. Moderate $\mathrm{K}$ compositions $(0<\mathrm{x}<0.30)$ exhibited significantly longer minority carrier lifetimes $[52,53]$, relative to $\mathrm{x} \sim 0$ and $\mathrm{x} \geq 0.30$. Superior $\mathrm{PV}$ performance was also observed at $\mathrm{x} \sim 0.07$ 
for a Ga-alloyed film with $\mathrm{Ga} /(\mathrm{Ga}+\mathrm{In}) \sim 0.3$ [10]. The Na composition at the substrate surface was also found to influence the amount of CKIS alloy formation during growth, relative to mixed-phase CuInSe $\mathrm{KInSe}_{2}$ formation [35]. Those studies are extended in the present work to detail the constitution of the deposited film as a function of overall composition and temperature in the $\mathrm{Cu}-\mathrm{K}-\mathrm{In}-\mathrm{Se}$ system at compositions of interest for PV applications. KF PDTs lead to very thin chemically modified layers that are difficult to characterize and may lead to non-reproducibility. In contrast, the present work used temperature to affect changes in films that were easily observable with basic characterization-providing insight into $\mathrm{Cu}-\mathrm{K}-\mathrm{In}-\mathrm{Se}$ chemistry. The conclusions drawn in this work have been utilized in subsequent papers to explain phenomena in highly efficient $\mathrm{Cu}_{1-\mathrm{x}} \mathrm{K}_{\mathrm{x}} \mathrm{InSe}_{2}$ [54] and $\mathrm{Cu}_{1-\mathrm{x}} \mathrm{K}_{\mathrm{x}} \mathrm{In}_{1-\mathrm{y}} \mathrm{Ga}_{\mathrm{y}} \mathrm{Se}_{2}$ [55] solar cells, confirming the usefulness of the present materials chemistry study.

\section{Experimental}

Most CIGS films are grown with $\mathrm{Ga} /(\mathrm{Ga}+\mathrm{In}) \sim 0.2-0.3$ and intentional cation composition gradients $[1,56,57]$. In this study, however, Ga has been excluded to simplify data interpretation. A constant rate, single temperature process was also chosen to achieve uniformity in depth and avoid compositional gradients, as $\mathrm{K}[15,47]$ and $\mathrm{Na}[58,59]$ have been shown to affect cation diffusion in CIGS. Co-evaporation of $\mathrm{Cu}, \mathrm{KF}$, In, and Se was performed on SLG and SLG/Mo ("Mo") substrates at $400^{\circ} \mathrm{C}, 500^{\circ} \mathrm{C}$, or $600^{\circ} \mathrm{C}$, as previously detailed [53]. The group I to III cation atomic ratio, $(\mathrm{K}+\mathrm{Cu}) / \mathrm{In}$, in the film was maintained near 0.85 for all depositions, while $\mathrm{x}$ was varied between 0 and 1 . Deposited film composition was measured with X-ray fluorescence (XRF; Fischerscope X-ray XDV-SDD with a W anode, $10 \mu \mathrm{m}$ Ni filter, and silicon drift detector), secondary ion mass spectrometry (SIMS), and energy dispersive X-ray 
spectroscopy (EDS on a transmission electron microscope). As noted [53], peak overlap between $\mathrm{K}$ and In reduces the certainty of XRF and EDS composition measurement, thus film compositions from in situ electron impact emission spectroscopy (EIES) and quartz crystal microbalance data were used unless otherwise noted. Interference between ${ }^{39} \mathrm{~K}^{41} \mathrm{~K}^{+}$and ${ }^{80} \mathrm{Se}^{+}$ ions was observed during SIMS measurements on films with high $\mathrm{K}$ content $(\mathrm{x} \geq 0.38)$, so ${ }^{76} \mathrm{Se}^{+}$ ions were used to determine the Se composition. Symmetric X-ray diffraction (XRD) was performed with a Rigaku Ultima IV diffractometer to determine structure and assist in phase identification, as previously reported [53]. Standard diffraction patterns were calculated from published phase structures $[53,60,61]$. Film morphology was observed using scanning electron microscopy (SEM). Ultraviolet-visible (UV-visible) spectroscopy was performed to measure transmissivity and reflectivity of SLG/Cu-K-In-Se samples using a Cary 5000 spectrophotometer with a diffuse reflectance-integrating sphere. Film thicknesses were measured with a Dektak 8 profilometer.

Through-film resistivity was measured with SLG/Mo/CKIS/Ni structures. Electron-beam evaporation of $\sim 50 \mathrm{~nm} \mathrm{Ni}$, followed by $\sim 3 \mu \mathrm{m} \mathrm{Al}$ through $\sim 1.5 \mathrm{~mm}^{2}$ apertures (normally used for solar cell grids) formed top contacts for current-voltage (IV) measurements, which were performed on a temperature-controlled stage at $25^{\circ} \mathrm{C}$. Room temperature time-resolved photoluminescence (TRPL) was performed on absorber films with a $905 \mathrm{~nm}$ laser $(1.37 \mathrm{eV})$ under low-injection conditions, and the response was detected with a near-infrared photomultiplier tube responsive to photons in the range 0.92 to $1.31 \mathrm{eV}$. A detailed description of the fiber optic system was published elsewhere [62]. Peak TRPL signals were used to estimate majority carrier concentrations by assuming a constant radiative coefficient for all samples, and single exponential functions were fitted to decays curves to estimate minority carrier lifetimes. 
Phase changes and reactions were followed as a function of time and temperature in situ using high temperature XRD (HTXRD). In these experiments, a co-evaporated film was placed in a SiC-coated graphite chamber fitted with $\mathrm{Al}$ windows to allow heating along with elemental Se. The chamber was heated up to $600^{\circ} \mathrm{C}$ while symmetric HTXRD was performed. Temperature was increased in increments of 10 or $20^{\circ} \mathrm{C}$, followed by $8 \mathrm{~min}$ XRD scans at constant temperature. For dwells, the temperature was rapidly ramped $\left(100^{\circ} \mathrm{C} / \mathrm{min}\right)$ to the set point, and held for the duration of the scans. Films were annealed in vacuum (base pressure $<3 \times 10^{-6}$ Torr) by supplying evaporated Se, heating at $100^{\circ} \mathrm{C} / \mathrm{min}$ to $600^{\circ} \mathrm{C}$, then holding for $10-80 \mathrm{~min}$, and finally cooling at $20^{\circ} \mathrm{C} / \mathrm{min}$ to room temperature. The anneals were performed at $600^{\circ} \mathrm{C}$ to affect changes in the films grown at $400^{\circ} \mathrm{C}$ and $500^{\circ} \mathrm{C}$ that would be easily observable, and the HTXRD data provided additional insight into what would occur at other annealing temperatures.

\section{Results}

\subsection{Effect of growth temperature}

The substrate surface's Na content determined the extent of CKIS alloy formation [35]. High and low Na substrates were therefore employed to study the effect of temperature.

\subsubsection{High Na substrates (SLG)}

Baseline films of nominally $\mathrm{CuInSe}_{2}(\mathrm{x} \sim 0)$ were grown at $500^{\circ} \mathrm{C}$ for comparative purposes. These absorbers had narrower, more intense XRD peaks and more precipitous absorptivity onsets by UV-visible spectroscopy, relative to films grown at $400^{\circ} \mathrm{C}$ (not shown). These results are consistent with enhanced crystallinity at higher growth temperature. In addition 
the $\mathrm{CuInSe} \mathrm{I}_{2}$ films did not exhibit shifts in either XRD peak positions or band gap energies with growth temperature.

Films of $\mathrm{Cu}-\mathrm{K}-\mathrm{In}-\mathrm{Se}$ with group I composition $\mathrm{x} \sim 0.38$ were grown on SLG substrates at 500 and $600^{\circ} \mathrm{C}$. The $500^{\circ} \mathrm{C}$ film was homogenous and exhibited a finer grain structure, suggesting an increased nucleation rate at the lower deposition temperature relative to the $600^{\circ} \mathrm{C}$ film (Fig. 1). On the other hand, the $600^{\circ} \mathrm{C}$ film exhibited segregation of large, planar crystals (right of Fig. 1; marked with yellow arrows). These precipitates appeared to be $\mathrm{KInSe}_{2}$, based on previous reports of SEM, XRD, and UV-visible spectroscopy on $\mathrm{KInSe}_{2}$ films [53], and $\mathrm{SEM} / \mathrm{EDS}$ on 2-phase $\mathrm{CuInSe}_{2}+\mathrm{KInSe}_{2}$ films [35]. The differences between films grown on SLG at 500 and $600^{\circ} \mathrm{C}$ were similar to those between SLG and Mo substrates previously reported at $500^{\circ} \mathrm{C}$ [35], where low temperature and high $\mathrm{Na}$ favored CKIS alloy growth. Films were also grown with $\mathrm{x} \sim 0.57$, and room temperature XRD patterns of the CKIS film grown at $500^{\circ} \mathrm{C}$ revealed that the CKIS alloy formation reaction was complete (Fig. 2), as inferred from chalcopyrite lattice parameter reduction (from 5.770 to $5.725 \AA$ [53]). The $600^{\circ} \mathrm{C}$ film revealed reflections consistent with chalcopyrite $\mathrm{x} \sim 0(\mathrm{CuInSe})$, as well as $\mathrm{K}_{2} \mathrm{In}_{12} \mathrm{Se}_{19}$ and $\mathrm{KInSe}_{2}$. The XRD results were corroborated by UV-visible spectroscopy. Specifically, the $500^{\circ} \mathrm{C}$ film had a weak absorptivity onset that was nonlinear in the Tauc plot, and yielded a band gap of $1.28 \pm$ $0.06 \mathrm{eV}$ (Fig. S1), as expected for a CKIS film with $\mathrm{x} \sim 0.57$ [53]. The $600^{\circ} \mathrm{C}$ film had two absorptivity transitions, which were linear in the Tauc plot, and yielded band gap values of 0.90 $\pm 0.05 \mathrm{eV}$ and $2.50 \pm 0.04 \mathrm{eV}$, which are similar to those for $\mathrm{CuInSe}_{2}$ and $\mathrm{KInSe}_{2}(1.05$ and 2.71 $\mathrm{eV}$ [53]). The nonlinearity in the $500^{\circ} \mathrm{C}$ film reduced the certainty of its band gap, and the $600^{\circ} \mathrm{C}$ film's mixed phases violated the assumptions for extrapolating band gap with a Tauc plot, so these values are considered approximate. 


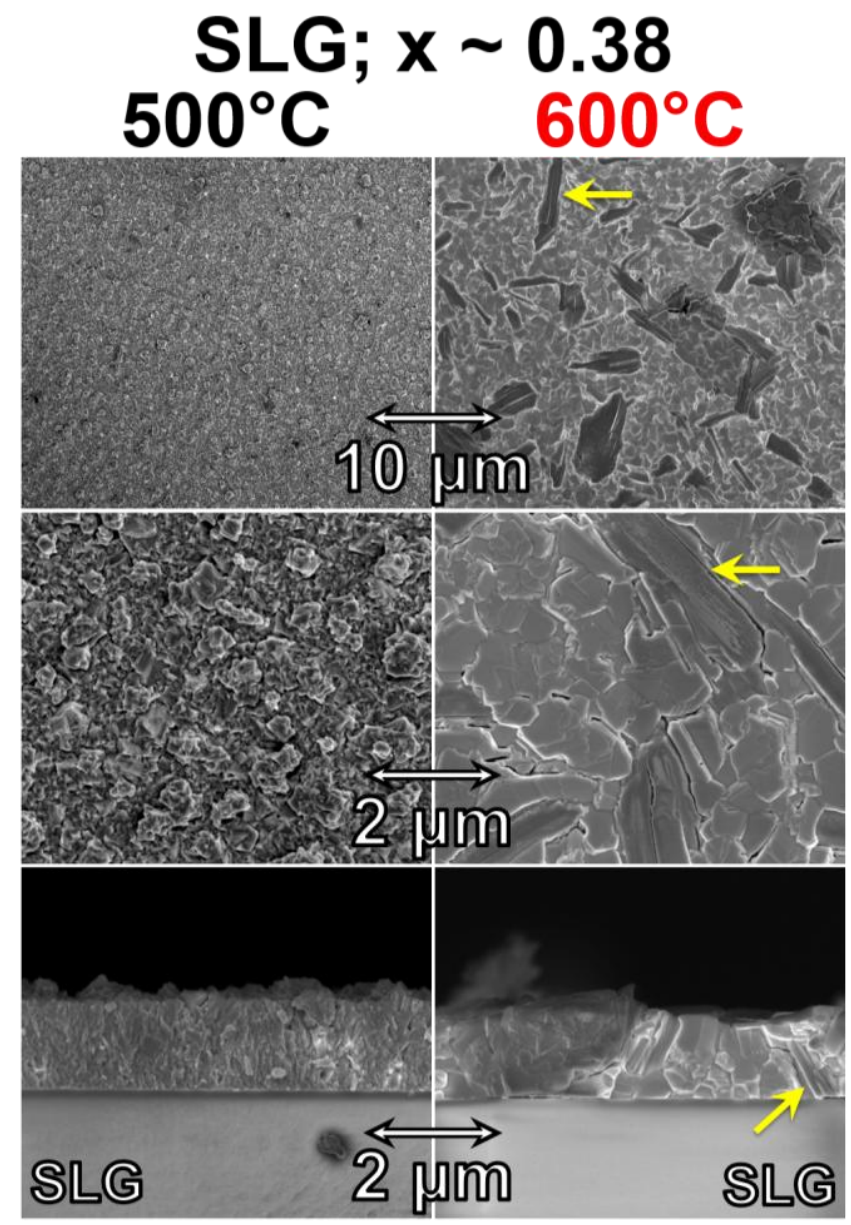

Fig. 1. Plan view (top and middle) and cross-sectional (bottom) SEM micrographs of Cu-K-In-Se films with $\mathrm{x} \sim 0.38$ grown on SLG at $500^{\circ} \mathrm{C}$ (left) and $600^{\circ} \mathrm{C}$ (right). $\mathrm{KInSe}_{2}$ crystals are marked by yellow arrows. 


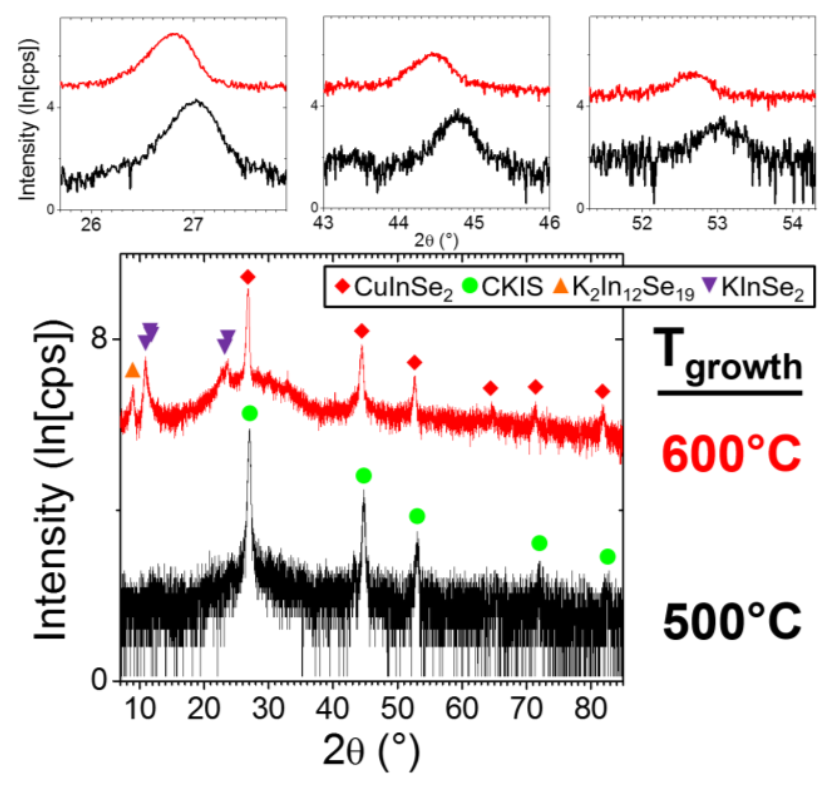

Fig. 2. Room temperature symmetric XRD patterns from $\mathrm{Cu}-\mathrm{K}-\mathrm{In}-\mathrm{Se}$ films with $\mathrm{x} \sim 0.57$ grown on SLG at $600^{\circ} \mathrm{C}$ (top; red) and $500^{\circ} \mathrm{C}$ (bottom; black), with magnified (112), (204)/(220), and (116)/(312) peak ranges above. CuInSe 2 , CKIS, $\mathrm{K}_{2} \mathrm{In}_{12} \mathrm{Se}_{19}$, and $\mathrm{KInSe} \mathrm{I}_{2}$ peaks are indicated by red diamonds, green circles, orange up triangles, and purple down triangles, respectively. The CKIS peak positions correspond to a composition of $\mathrm{x} \sim 0.57$ [53].

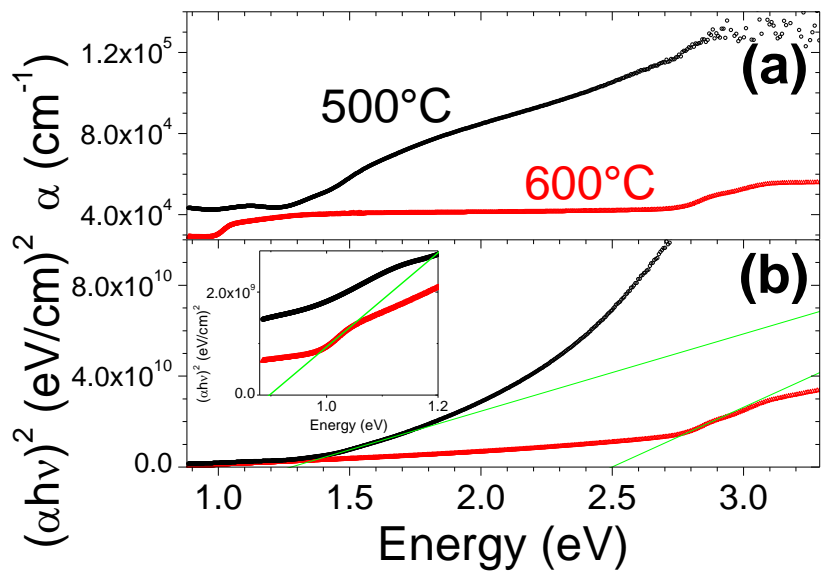


Fig. S1. (a) Absorptivity, $\alpha$, and (b) Tauc plot, $(\alpha h v)^{2}$ versus photon energy for Cu-K-In-Se with $\mathrm{x} \sim 0.57$ grown on $\mathrm{SLG}$ at $500^{\circ} \mathrm{C}$ (black circles) and $600^{\circ} \mathrm{C}$ (red triangles). Example least squares fits (green lines in (b) and (b) inset) extrapolated to $1.28 \pm 0.06,0.90 \pm 0.05$, and $2.50 \pm 0.04 \mathrm{eV}$.

\subsubsection{Low Na substrates (Mo)}

The use of Mo substrates was previously shown to establish 3x less $\mathrm{Na}$ in the growing $\mathrm{Cu}-\mathrm{K}-\mathrm{In}-\mathrm{Se}$ films by SIMS, relative to SLG substrates [35]. The effect of temperature on Nadeficient growth was studied for $\mathrm{Cu}-\mathrm{K}$-In-Se films with $\mathrm{x} \sim 0$ and 0.38 on $\mathrm{Mo}$ at $400^{\circ} \mathrm{C}$ and $500^{\circ} \mathrm{C}$. The $\mathrm{x} \sim 0$ film exhibited enhanced crystallinity at higher growth temperature, but no XRD peak shifts (not shown). Fig. 3 collects typical cross-sectional and plan-view SEM images of films with $\mathrm{x} \sim 0.38$ grown at $400^{\circ} \mathrm{C}$ and $500^{\circ} \mathrm{C}$. The composition of the film grown at $500^{\circ} \mathrm{C}$ (Fig. 3, right) was determined by EDS as $20.5 \pm 1.4 \mathrm{Cu}, 10.6 \pm 1.0 \mathrm{~K}, 18.1 \pm 0.8 \mathrm{In}$, and $50.9 \pm$ 2.0 Se (at. \%) to give $\mathrm{x} \sim 0.341 \pm 0.030$. This is in rough agreement with the values from in situ measurement $(13.8 \mathrm{Cu}, 8.6 \mathrm{~K}, 27.6 \mathrm{In}$, and 50.0 Se (at. \%); $\mathrm{x} \sim 0.376)$. The film grown at $400^{\circ} \mathrm{C}$ (Fig. 3, left) was homogenous, and had a finer grain structure, relative to growth at $500^{\circ} \mathrm{C}$ (Fig. 3 , right). This could relate to an increased nucleation rate, which would be expected at lower growth temperature. The $500^{\circ} \mathrm{C}$ film included large, planar $\mathrm{KInSe}_{2}$ precipitates (right of Fig. 3; marked with yellow arrows). Films were also grown under the same conditions as those depicted in Fig. 3 but with higher $\mathrm{K}, \mathrm{x} \sim 0.57$. Similarly, the film grown at $400^{\circ} \mathrm{C}$ was completely alloyed CKIS, while the $500^{\circ} \mathrm{C}$ film was 2-phase $\mathrm{CuInSe}_{2}+\mathrm{KInSe}_{2}$ (Fig. 4). Thus, changing growth temperature and substrate Na revealed very similar trends in phase growth [35]. The $400^{\circ} \mathrm{C}$ film had additional peaks at 17.9 and $29.6^{\circ} 2 \theta$. These peaks were also observed in a similarly grown $\mathrm{x}$ 0.38 film (not shown), only shifted to larger d-spacing. Previous reports on bulk 
$\mathrm{Cu}_{0.33} \mathrm{~K}_{0.67} \mathrm{InSe}_{2}$ crystals found monoclinic symmetry $[63,64]$. The new XRD peaks could relate to the structural transition from tetragonal $\mathrm{CuInSe}_{2}$ to monoclinic $\mathrm{Cu}_{0.33} \mathrm{~K}_{0.67} \mathrm{InSe}_{2}$, warranting future study.

The resistivity of films grown on $\mathrm{Mo}$ at $400^{\circ} \mathrm{C}$ was measured for Mo/CKIS/Ni stacks with varied $\mathrm{x}$ composition. Increasing $\mathrm{x}$ decreased apparent resistivity at $0 \mathrm{~V}$ and in reverse bias (Fig. S2), and indicated a current blocking barrier for the Mo and/or Ni interface [53]. The resistivity of films grown at $400^{\circ} \mathrm{C}$ was larger than films grown at $500^{\circ} \mathrm{C}$ by roughly 2 decades [53], while the trends with composition changes were similar for each growth temperature. The correlation between apparent resistivity and $\mathrm{K}$ composition may therefore be unrelated to the intragranular properties of the $\mathrm{CuInSe}_{2}$, CKIS, or $\mathrm{KInSe}_{2}$ crystals. As noted [53], some undetected grain boundary-segregated phase could dominate the apparent resistivity changes [65]. Bulk crystal resistivity measurements could help discern this effect. Films grown on Mo had superior lifetimes by TRPL, relative to SLG substrates. TRPL electron lifetimes and hole concentrations for $\mathrm{Cu}-\mathrm{K}$-In-Se films grown on $\mathrm{Mo}$ at $400^{\circ} \mathrm{C}, 500^{\circ} \mathrm{C}$, and $600^{\circ} \mathrm{C}$ at different $\mathrm{x}$ compositions are compared in Fig. S3. Growth temperature and composition changed the phase constitution of the films and their semiconducting properties, so the mechanisms responsible for the trends in Fig. S3 are unclear. Further study with spectrally resolved TRPL would contribute to understanding the connections between improved lifetimes and CKIS alloy formation or consumption. 


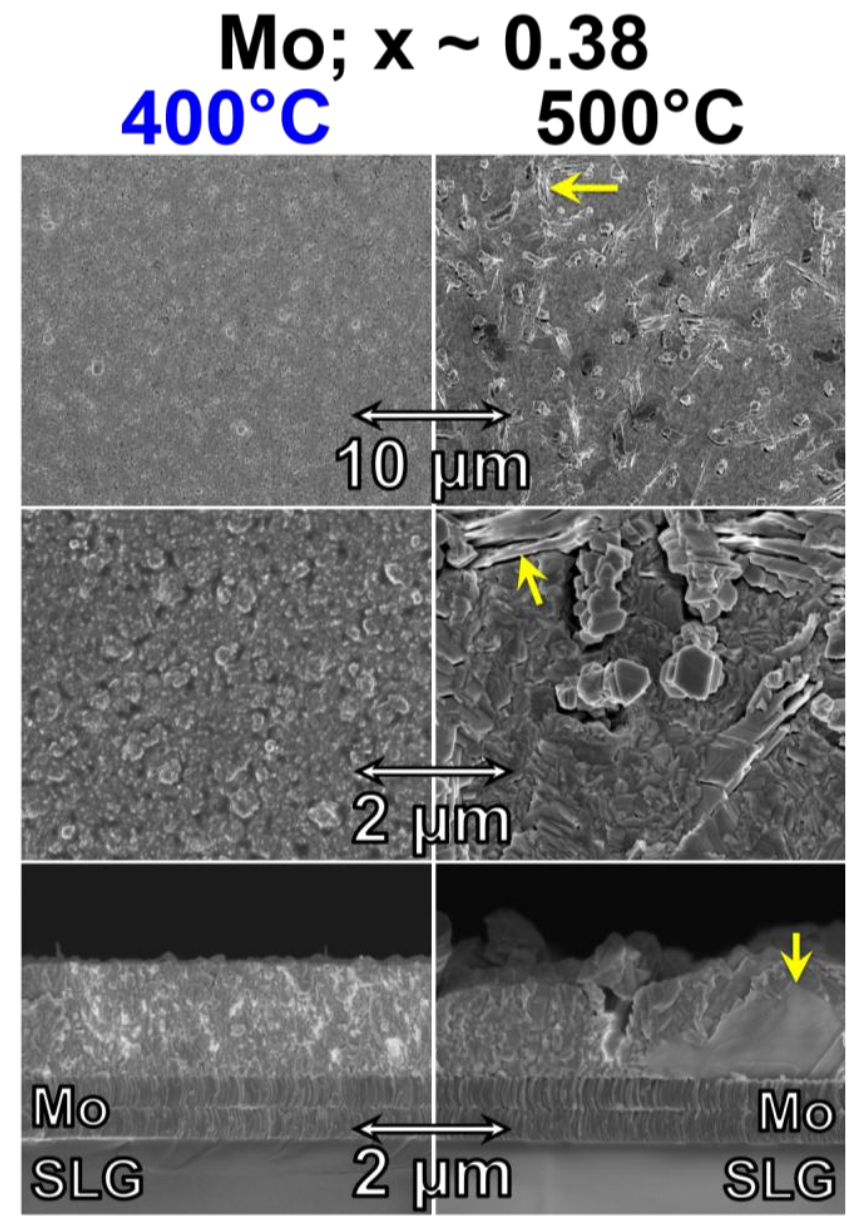

Fig. 3. Plan view (top) and cross-sectional (bottom) SEM micrographs of Cu-K-In-Se films with $\mathrm{x} \sim 0.38$ grown on $\mathrm{Mo}$ at $400^{\circ} \mathrm{C}$ (left) and $500^{\circ} \mathrm{C}$ (right). $\mathrm{KInSe}_{2}$ crystals are marked by yellow arrows. 


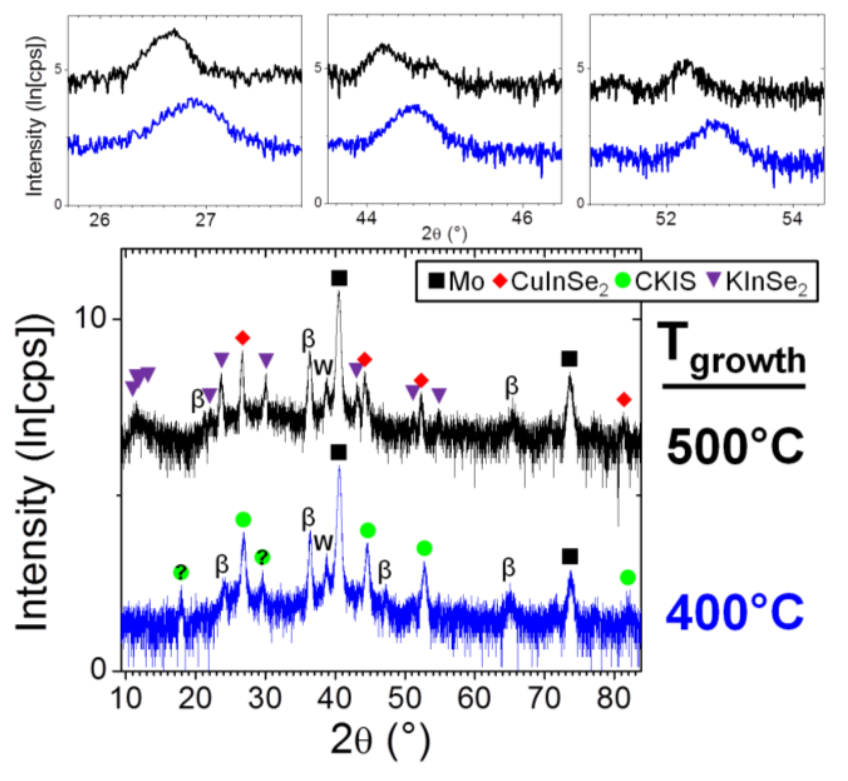

Fig. 4. Room temperature symmetric XRD scans from $\mathrm{Cu}-\mathrm{K}-\mathrm{In}-\mathrm{Se}$ films with $\mathrm{x} \sim 0.57$ grown on Mo at $500^{\circ} \mathrm{C}$ (top; black) and $400^{\circ} \mathrm{C}$ (bottom; blue), with magnified (112), (204)/(220), and (116)/(312) peak ranges above. Mo, $\mathrm{CuInSe}_{2}, \mathrm{CKIS}$, and $\mathrm{KInSe}_{2}$ peaks are labeled with black squares, red diamonds, green circles, and purple triangles, respectively. The CKIS peak positions correspond to a composition of $\mathrm{x} \sim 0.57$ [53]. The question mark (?) denotes uncertainty in the peak assignment. ' $\beta$ ' and ' $\mathrm{W}$ ' peaks are from $\mathrm{Cu} \mathrm{K}_{\beta}$ and $\mathrm{W}$ impurity in the $\mathrm{Cu}$ radiation source.

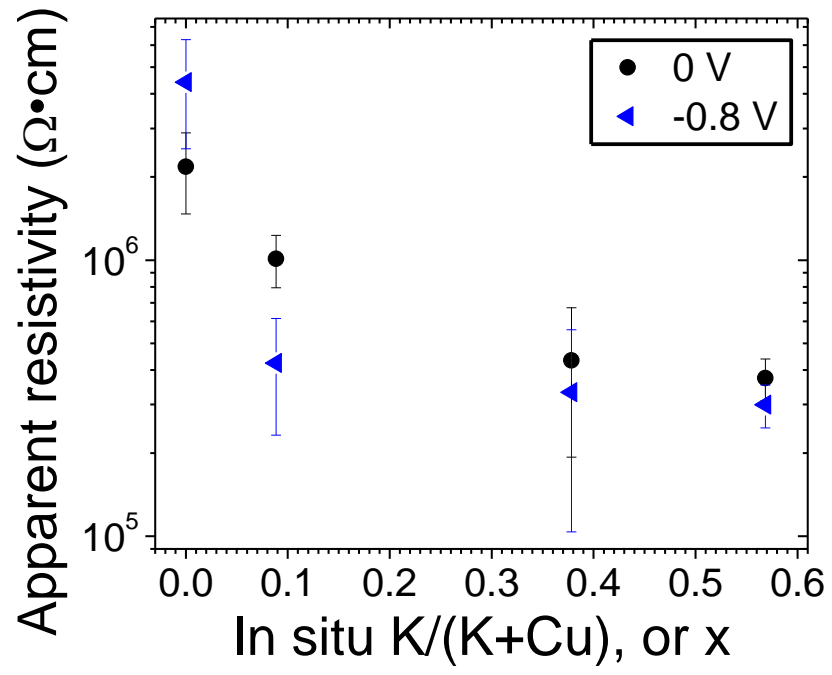


Fig. S2. Apparent resistivity at $0 \mathrm{~V}$ bias (black circles) and $-0.8 \mathrm{~V}$ bias (blue triangles) of $\mathrm{Mo} / \mathrm{CKIS} / \mathrm{Ni}$ versus in situ $\mathrm{x}$ composition of the CKIS. CKIS was grown at $400^{\circ} \mathrm{C}$, and standard deviations from multiple contacts are shown as error bars.

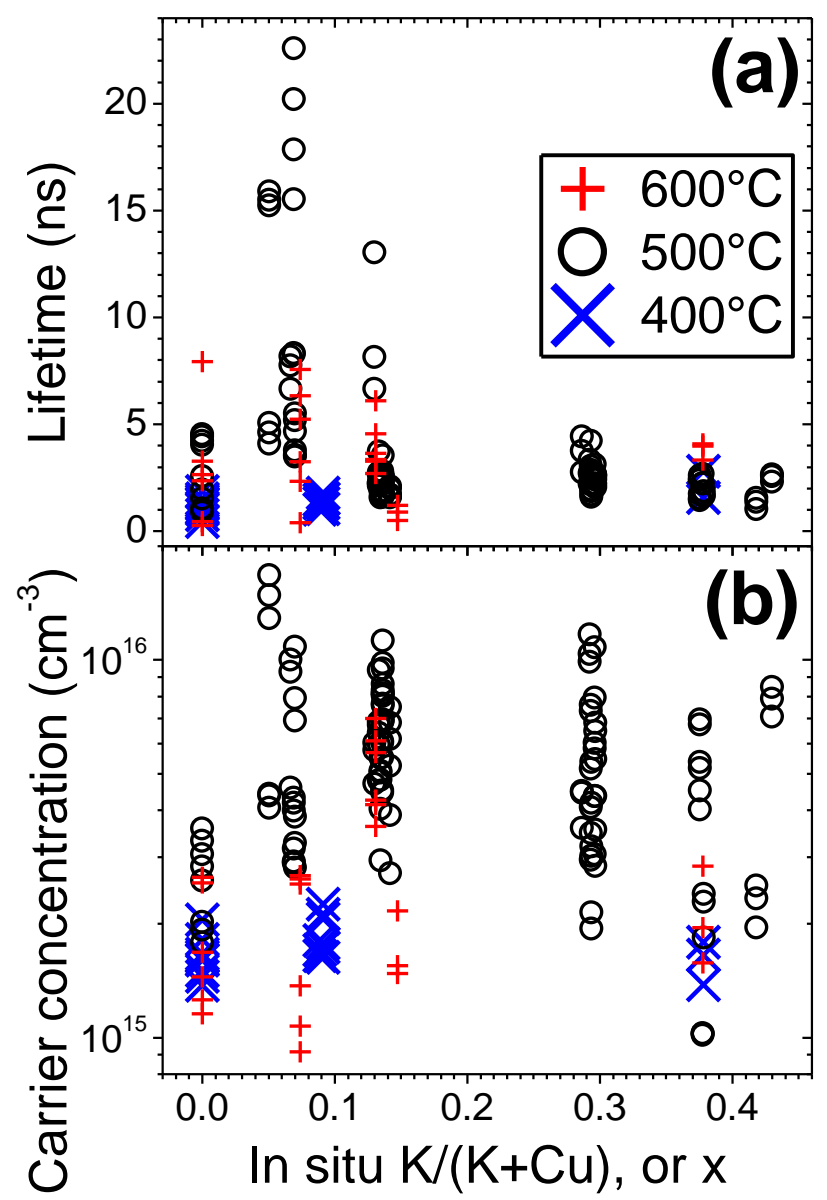

Fig. S3. Minority carrier lifetime (a) and majority carrier concentration (b) from TRPL versus in situ x composition of the $\mathrm{Cu}-\mathrm{K}-\mathrm{In}-\mathrm{Se}$ grown on $\mathrm{Mo}$ at $600^{\circ} \mathrm{C}$ (red plusses), $500^{\circ} \mathrm{C}$ (black circles), and $400^{\circ} \mathrm{C}$ (blue crosses).

The effect of growth parameters on the extent of the following net reaction was further solidified:

$\mathrm{CuInSe}_{2}+\mathrm{KInSe}_{2} \longleftrightarrow 2 \mathrm{Cu}_{0.5} \mathrm{~K}_{0.5} \mathrm{InSe}_{2}$ 
Switching from low to high $\mathrm{Na}$ substrates at $500^{\circ} \mathrm{C}$ was previously shown to favor the forward reaction. In this study, switching from high to low temperature was shown to further drive the reaction forward. Remarkably similar effects were observed for the following 3 process changes: from Mo to SLG at $500^{\circ} \mathrm{C}$ [35], from $600^{\circ} \mathrm{C}$ to $500^{\circ} \mathrm{C}$ on SLG (Fig. 1, 2, and S1), and from $500^{\circ} \mathrm{C}$ to $400^{\circ} \mathrm{C}$ on $\mathrm{Mo}$ (Fig. 3 and 4). These data were chosen to succinctly represent key features of a much larger dataset (for instance, $500^{\circ} \mathrm{C}$ and $400^{\circ} \mathrm{C} \mathrm{SLG}$ data were similar, so the latter were excluded). Further study will be needed to determine the quantitative effects of $\mathrm{Na}$ and temperature, as well as the kinetic and/or thermodynamic origins of those effects. The effect of temperature was easily observed on samples with high $\mathrm{K} /(\mathrm{K}+\mathrm{Cu})$ compositions. At lower $\mathrm{K} /(\mathrm{K}+\mathrm{Cu})$ compositions, the magnitudes of lattice parameter and band gap shifts would make this effect difficult to observe with the presently employed methods. Future data on lower $\mathrm{K} /(\mathrm{K}+\mathrm{Cu})$ compositions could help clarify the role of a potential CKIS miscibility gap in the presently observed phase transitions. Upon reversal of reaction (1), the $\mathrm{CuInSe} \mathrm{S}_{2}$ precipitates could contain residual $\mathrm{K}$, where measurements of $\mathrm{K}$ solubility in bulk chalcopyrite CIGS crystals would help characterize this.

\subsection{Effect of annealing}

$\mathrm{Cu}-\mathrm{K}-\mathrm{In}-\mathrm{Se}$ films were grown on Mo and SLG substrates at 400 and $500^{\circ} \mathrm{C}$, and were then annealed to $600^{\circ} \mathrm{C}$ for $10-80$ min under vacuum. Regardless of substrate, deposition temperature, and annealing time, films exhibited more extensive growth of $\mathrm{KInSe}_{2}$ crystals after annealing, as evidenced by SEM (e.g. Fig. S4; marked with a yellow arrow). XRD and UVvisible spectroscopy measurements both showed that as-deposited CKIS alloys decomposed into $\mathrm{CuInSe}_{2}+\mathrm{KInSe}_{2}$ during anneals (Fig. S5 and S6), mirroring behavior at increased growth 
temperature (Fig. 2, 4, and S1). K-In-Se (x 1) films grown at $500^{\circ} \mathrm{C}$ predominantly contained $\mathrm{KInSe}_{2}$, although $\mathrm{K}_{2} \mathrm{In}_{12} \mathrm{Se}_{19}$ impurities were often detected in XRD measurements at low intensity [53]. The band gap of $\mathrm{K}_{2} \mathrm{In}_{12} \mathrm{Se}_{19}$ was determined to be $2.25 \pm 0.02 \mathrm{eV}$ by UV-visible spectroscopy (not shown), in qualitative agreement with its reported red appearance [66]. Annealing K-In-Se films to $600^{\circ} \mathrm{C}$ promoted partial decomposition of $\mathrm{KInSe}_{2}$ and formation of $\mathrm{K}_{2} \mathrm{In}_{12} \mathrm{Se}_{19}$ (Fig. S7). Subsequent humid air exposure caused spontaneous film delamination, preventing extensive characterization.

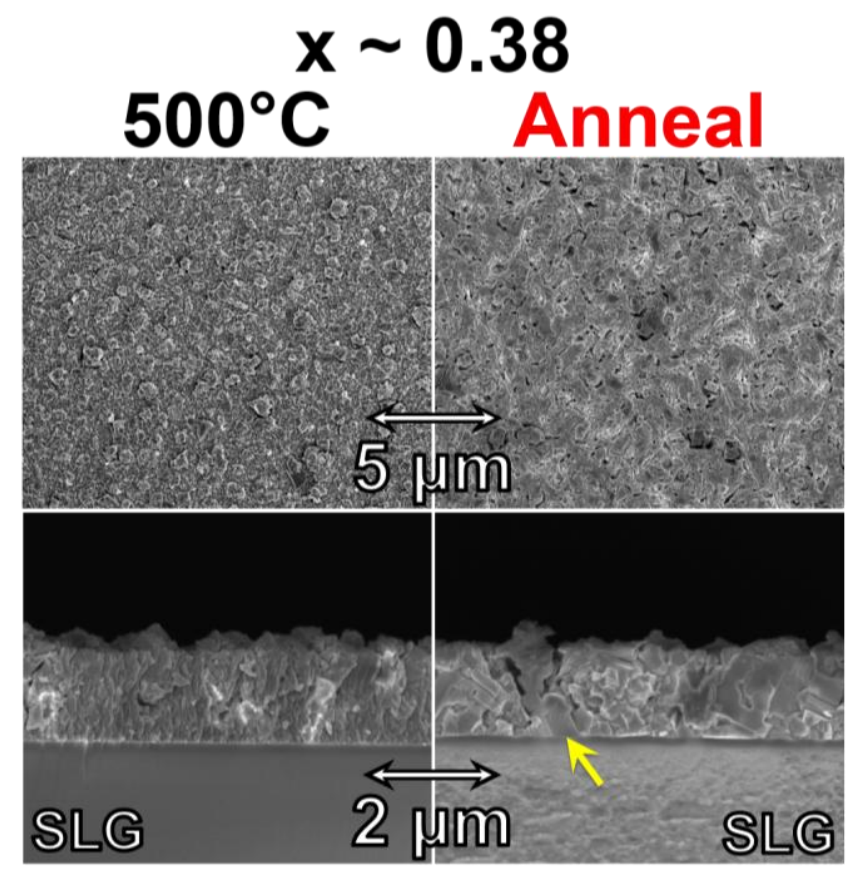

Fig. S4. Plan view (top) and cross-sectional (bottom) SEM micrographs of a Cu-K-In-Se film with $\mathrm{x} \sim 0.38$ grown on SLG at $500^{\circ} \mathrm{C}$ (left) and then annealed at $600^{\circ} \mathrm{C}$ for $10 \mathrm{~min}$ (right). $\mathrm{KInSe}_{2}$ crystals are marked by a yellow arrow. 

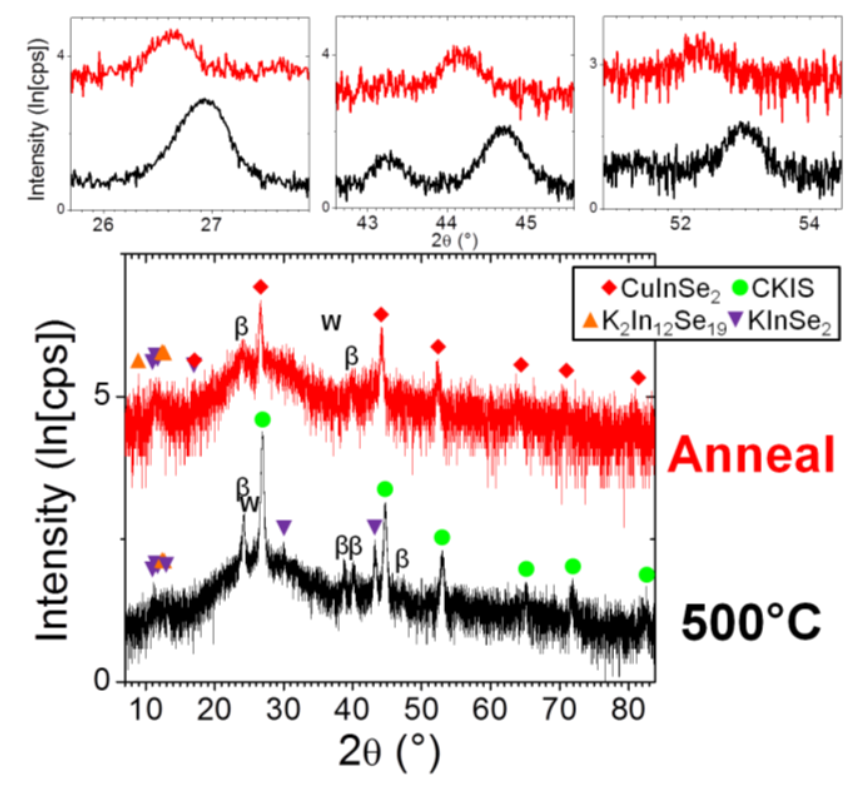

Fig. S5. Room temperature symmetric XRD scans from a Cu-K-In-Se film with $\mathrm{x} \sim 0.57$ grown on SLG at $500^{\circ} \mathrm{C}$ (bottom; black), and then annealed at $600^{\circ} \mathrm{C}$ for $10 \mathrm{~min}$ (top; red), with magnified (112), (204)/(220), and (116)/(312) peak ranges above. Peaks attributed to $\mathrm{CuInSe}_{2}$, CKIS, $\mathrm{K}_{2} \mathrm{In}_{12} \mathrm{Se}_{19}$, and $\mathrm{KInSe} \mathrm{S}_{2}$ are labeled with red diamonds, green circles, orange up triangles, and purple down triangles, respectively. The CKIS peak positions correspond to a composition of $\mathrm{x} \sim 0.57$ [53]. ' $\beta$ ' and 'W' peaks are from $\mathrm{Cu} \mathrm{K}_{\beta}$ and $\mathrm{W}$ impurity in the $\mathrm{Cu}$ radiation source.

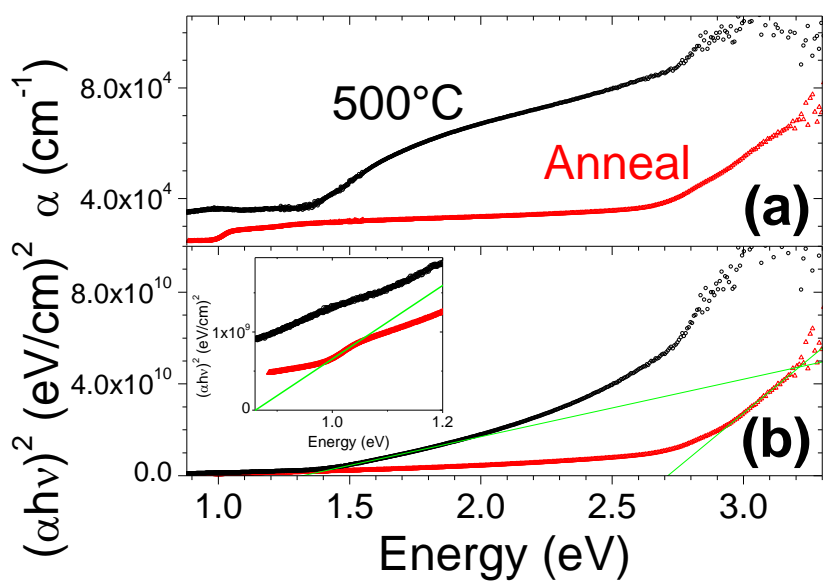

Fig. S6. (a) Absorptivity, $\alpha$, and (b) Tauc plot, $(\alpha h v)^{2}$, versus photon energy for CKIS with $\mathrm{x} \sim$ 0.57 grown on $\mathrm{SLG}$ at $500^{\circ} \mathrm{C}$ (black circles) and then annealed at $600^{\circ} \mathrm{C}$ for $10 \mathrm{~min}$ (red 
triangles). Example least squares fits (green lines in (b) and (b) inset) extrapolated to $1.32 \pm 0.06$, $0.86 \pm 0.05$, and $2.71 \pm 0.02 \mathrm{eV}$.

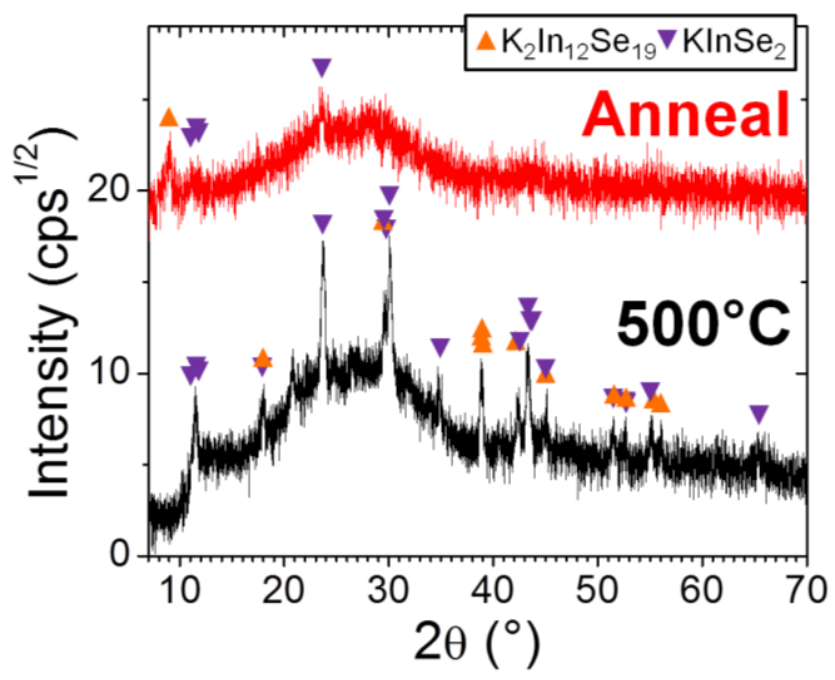

Fig. S7. Room temperature symmetric XRD scans from a K-In-Se film $(\mathrm{x} \sim 1)$ grown on SLG at $500^{\circ} \mathrm{C}$ (bottom; black), and then annealed at $600^{\circ} \mathrm{C}$ for $80 \mathrm{~min}$ (top; red). $\mathrm{K}_{2} \mathrm{In}_{12} \mathrm{Se}_{19}$ and $\mathrm{KInSe}_{2}$ peaks are labeled with orange up triangles and purple down triangles, respectively.

HTXRD directly probed the phase transitions as a function of temperature. In the first study, a CKIS alloy with $\mathrm{x} \sim 0.57$ (grown at $400^{\circ} \mathrm{C}$ on $\mathrm{SLG}$ ) was slowly heated to $600^{\circ} \mathrm{C}$. Temperature was increased in 10 or $20^{\circ} \mathrm{C}$ increments, followed by constant temperature XRD scans ( 8 min each), and Fig. 5 shows their evolution. The sample initially showed reflections for only the CKIS alloy, but $\mathrm{KInSe}_{2}$ peaks appeared in the $290-450^{\circ} \mathrm{C}$ temperature range. Near $410^{\circ} \mathrm{C}$, the CKIS developed (204)/(220) texture $\left(44.4^{\circ} 2 \theta\right.$ peak). At $430^{\circ} \mathrm{C}$ the background signal increased, possibly due to a phase transition or recrystallization (e.g. the $\mathrm{L}<-->\mathrm{K}_{2} \mathrm{Se}+\mathrm{K}_{2} \mathrm{Se}_{2}$ invariant reaction was reported near $\left.430^{\circ} \mathrm{C}[67,68]\right)$. In the temperature range $420-450^{\circ} \mathrm{C}$ the CKIS peaks abruptly shifted to larger d-spacing, and very intense $\mathrm{KInSe}_{2}$ peaks simultaneously appeared. These changes are a result of reaction (1), and they corroborate previous studies [35, 
52-55, 63, 64, 69] that found decreased apparent lattice parameters as $\mathrm{x}$ was increased in CKIS alloys, despite the larger atomic radius of $\mathrm{K}$ relative to $\mathrm{Cu}$. The $\mathrm{KInSe}_{2}$ peaks at $460^{\circ} \mathrm{C}$ corresponded to $1 \%$ larger $\mathrm{a}, \mathrm{b}$, and $\mathrm{c}$ lattice parameters. As the temperature step-ramp continued, however, the $\mathrm{KInSe}_{2}$ lattice continuously compressed isotropically (i.e. peaks at greater $2 \theta$ displayed greater shifts). An unidentified peak shifted to smaller $2 \theta$ values in Fig. 5 $\left(50^{\circ} 2 \theta\right.$ and $\left.520^{\circ} \mathrm{C}\right)$.

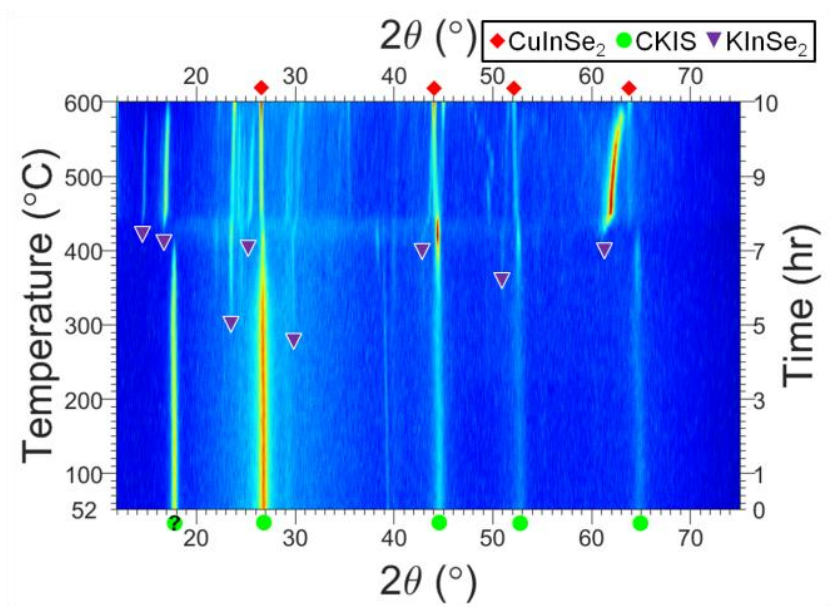

Fig. 5. HTXRD temperature ramp for SLG/CKIS with $\mathrm{x} \sim 0.57$ grown at $400^{\circ} \mathrm{C}$. CuInSe ${ }_{2}$, CKIS, and enlarged-lattice-KInSe ${ }_{2}$ peaks are labeled with red diamonds, green circles, and purple triangles, respectively. The CKIS peak positions correspond to a composition of $\mathrm{x} \sim 0.57$ [53]. The enlarged-lattice-KInSe 2 peaks were calculated with a $1 \%$ increase in the, $b$, and c lattice parameters. The question mark (?) denotes uncertainty in the peak assignment.

To better understand the origin of the peak shifts at high temperature observed in Fig. 5, two additional HTXRD experiments were performed on a K-In-Se film $(\mathrm{x} \sim 1$; grown on SLG at $500^{\circ} \mathrm{C}$ ): one with a rapid temperature ramp to $550^{\circ} \mathrm{C}$ followed by a series of isothermal scans, and a second temperature ramp. The dwell at $550^{\circ} \mathrm{C}$ (Fig. 6 (a)) also exhibited substantial peak shifts, indicative of a kinetic-limited reaction. The temperature ramp showed that the $\mathrm{K}_{2} \mathrm{In}_{12} \mathrm{Se}_{19}$ 
$+\mathrm{KInSe}_{2}$ two-phase film recrystallized into $\mathrm{KInSe}_{2}$ near $410-450^{\circ} \mathrm{C}$ (Fig. 6 (b)). The high temperature $\mathrm{KInSe}_{2}$ peaks then shifted to smaller d-spacing as temperature and time increased, similar to the shifts of Fig. 5 and 6 (a). Other peaks shifted to smaller $2 \theta$ values in Fig. 6 (a) and (b) (near $31,42,50,55$, and $60^{\circ} 2 \theta$ and $0 \mathrm{hr}$, and $32,42,50,55$, and $61^{\circ} 2 \theta$ and $520^{\circ} \mathrm{C}$, respectively), although the source of those shifts was unclear. The background increase near $230^{\circ} \mathrm{C}$ in Fig. 6 (b) could be a result of Se, which melts at $221^{\circ} \mathrm{C}$. The background increase at $430^{\circ} \mathrm{C}$ in both Fig. 5 and 6 (b) may have emerged from a K-In-Se phase transition or recrystallization.

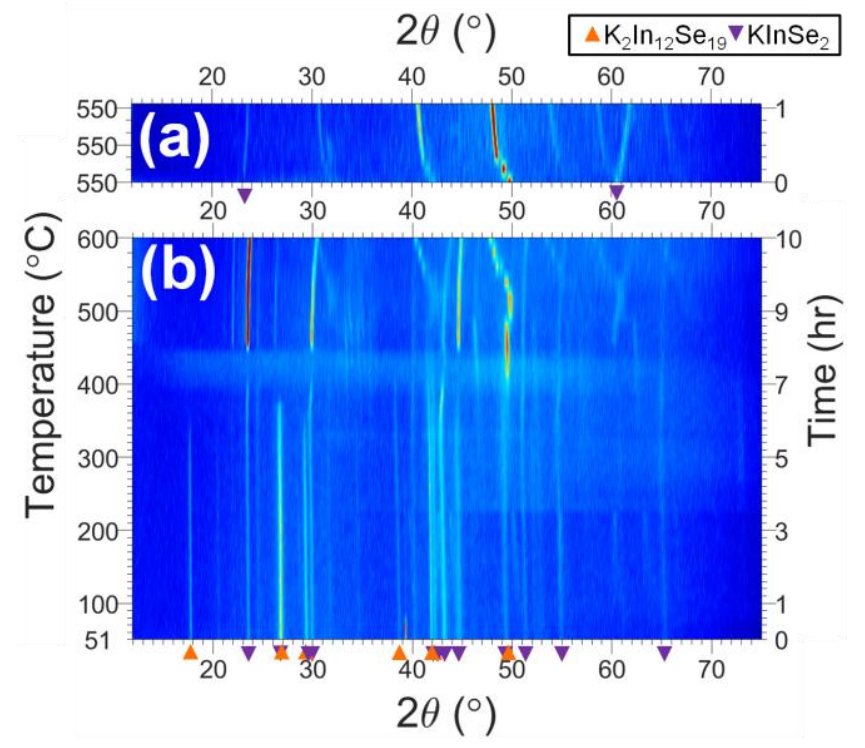

Fig. 6. HTXRD dwell at $550^{\circ} \mathrm{C}$ (a) and temperature ramp (b) for SLG/K-In-Se (i.e. $\mathrm{x} \sim 1$ ) grown at $500^{\circ} \mathrm{C} . \mathrm{K}_{2} \operatorname{In}_{12} \mathrm{Se}_{19}$ and $\mathrm{KInSe}_{2}$ peaks are labeled with orange up triangles and purple down triangles, respectively.

The XRF composition after vacuum anneals showed reduced $\mathrm{K}$ content for all $\mathrm{x}>0$, where more $\mathrm{K}$ loss occurred in films with greater initial K content (Fig. 7). A CuInSe 2 film (x 0) contained more $\mathrm{Na}$ and $\mathrm{K}$ by SIMS after a $600^{\circ} \mathrm{C}$ anneal (Table 1) that is attributed to $\mathrm{Na}$ and 
K out-diffusion from the substrate. However, the CKIS film with $\mathrm{x} \sim 0.38$ showed substantially less $\mathrm{K}$ by SIMS after annealing (Na increased similar to the $\mathrm{x} \sim 0$ case). The XRF and SIMS measurements demonstrated that $\mathrm{K}$ loss occurred during annealing, although residual $\mathrm{K}$ remained after 80 min anneals. As $\mathrm{K}$ loss occurred in addition to other phase transitions, any causal connection was unclear from the data.

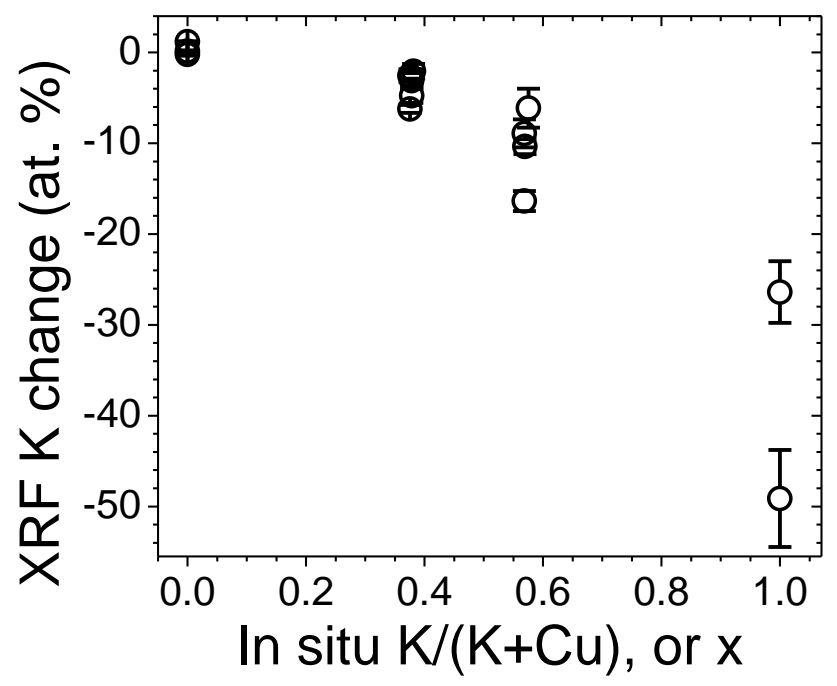

Fig. 7. Change in $\mathrm{K}$ composition by $\mathrm{XRF}$ after annealing $\mathrm{Cu}-\mathrm{K}-\mathrm{In}-\mathrm{Se}$ films at $600^{\circ} \mathrm{C}$, plotted against in situ $\mathrm{x}$ composition. Films were grown at $400^{\circ} \mathrm{C}$ and $500^{\circ} \mathrm{C}$, on SLG and Mo substrates, and annealed for 10,20 , or $80 \mathrm{~min}$.

Table 1. Na and K SIMS signals integrated over the film and divided by thickness for Cu-K-InSe films with in situ $\mathrm{x}$ of 0 and 0.38 grown at $500^{\circ} \mathrm{C}$ on $\mathrm{Mo}$, and then annealed at $600^{\circ} \mathrm{C}$ for 10 $\min$.

\begin{tabular}{cccc}
\hline $\mathrm{K} /(\mathrm{K}+\mathrm{Cu})$, or $\mathrm{x}$ & Sample & $\mathrm{Na}(\mathrm{cps} / \mu \mathrm{m})$ & $\mathrm{K}(\mathrm{cps} / \mu \mathrm{m})$ \\
\hline \multirow{2}{*}{0} & Anneal & $4.7 \times 10^{5}$ & $1.4 \times 10^{4}$ \\
& $500^{\circ} \mathrm{C}$ growth & $1.6 \times 10^{4}$ & $4.6 \times 10^{3}$ \\
\multirow{2}{*}{0.38} & Anneal & $2.3 \times 10^{6}$ & $1.0 \times 10^{6}$ \\
& $500^{\circ} \mathrm{C}$ growth & $7.0 \times 10^{5}$ & $3.0 \times 10^{6}$ \\
\hline
\end{tabular}


The SEM, XRD, UV-visible spectroscopy, and HTXRD results on samples annealed under vacuum and atmospheric pressure resembled results for growth temperature, where high temperature annealing reversed reaction (1). Annealing additionally consumed $\mathrm{KInSe}_{2}$ and produced $\mathrm{K}_{2} \mathrm{In}_{12} \mathrm{Se}_{19}$. However, relative phase amounts of $\mathrm{KInSe} \mathrm{I}_{2}$ and $\mathrm{K}_{2} \mathrm{In}_{12} \mathrm{Se}_{19}$ were difficult to distinguish due to peak overlap in XRD (e.g. Fig. S5) and similar band gaps: $2.71 \mathrm{eV}$ [52, 70] compared to $2.25 \pm 0.02 \mathrm{eV}$, respectively. It was therefore unclear if the $\mathrm{KInSe}_{2} \mathrm{decomposition}$ and $\mathrm{K}_{2} \mathrm{In}_{12} \mathrm{Se}_{19}$ formation was also driven by growth temperature, or just annealing. The combined XRF and SIMS results indicated that $\mathrm{K}$ loss occurred during the anneals. The reduction in $\mathrm{K}$ chemical potential during annealing achieved conditions unlike increasing growth temperature, as $\mathrm{K}$ chemical potential was held relatively constant in the latter.

Based on the combined XRD, UV-visible spectroscopy, HTXRD, XRF, and SIMS data, the following net reaction was favored at high temperature and reduced $\mathrm{K}$ chemical potential:

$$
12 \mathrm{KInSe}_{2}(\mathrm{~s}) \longrightarrow \underline{600^{\circ} \mathrm{C}} \longrightarrow \mathrm{K}_{2} \operatorname{In}_{12} \mathrm{Se}_{19}(\mathrm{~s})+5 \mathrm{~K}_{2} \mathrm{Se}(\mathrm{g})
$$

Here, the gaseous K-containing species was assumed to be $\mathrm{K}_{2} \mathrm{Se}$ for the sake of illustration, as no K-Se vapor pressure data has been published. The $\mathrm{KInSe}_{2}$ had (53-8)/(51-9)/(356)/(15-8) texture $\left(60.5-63^{\circ} 2 \theta\right.$ peaks $)$ in Fig. 5 and $6(\mathrm{~b})$, while it had $(22-2) /(221)$ texture $\left(23.7^{\circ} 2 \theta\right.$ peak $)$ in Fig. 6 (a). However, the contraction of the $\mathrm{KInSe}_{2}$ lattice at high temperature (Fig. 5, 6 (a), and 6 (b)) was apparently isotropic, so it may not stem from external stress. On the other hand, an isotropic reduction in $\mathrm{KInSe}_{2}$ lattice volume may be expected for the following reaction:

$10 \mathrm{KInSe}_{2}(\mathrm{~s})+\mathrm{Se}(\mathrm{g})-\underline{600^{\circ} \mathrm{C}} \longrightarrow 10 \mathrm{~K}_{0.8} \operatorname{InSe}_{2}(\mathrm{~s})+\mathrm{K}_{2} \mathrm{Se}(\mathrm{g})$ 
As shown, the formation of vacancies on $\mathrm{K}$ lattice sites $\left(\mathrm{Va}_{\mathrm{K}}\right)$ in $\mathrm{KInSe}_{2}$ could have accompanied the evaporative loss of $\mathrm{K}$. In this way, the observed $\mathrm{K}$ loss could cause the $\mathrm{KInSe}_{2}$ contraction observed at high temperature, as well as the $\mathrm{KInSe} \mathrm{e}_{2}$ consumption and $\mathrm{K}_{2} \mathrm{In}_{12} \mathrm{Se}_{19}$ formation.

Continuous peak shifts to smaller $2 \theta$ (larger d-spacing) were also found at $500-600^{\circ} \mathrm{C}$ in Fig. 5, 6 (a), and 6 (b). These were likely attributable to phase transitions. There were many candidate compounds: $\mathrm{In}_{4} \mathrm{Se}_{3}, \mathrm{InSe}, \mathrm{In}_{6} \mathrm{Se}_{7}, \mathrm{In}_{9} \mathrm{Se}_{11}, \mathrm{In}_{5} \mathrm{Se}_{7}, 4$ polymorphs of $\operatorname{In}_{2} \mathrm{Se}_{3}$ [71], $\mathrm{K}_{2} \mathrm{In}_{12} \mathrm{Se}_{19}$ [60], the $\mathrm{Se}$ analog of $\mathrm{KIn}_{5} \mathrm{~S}_{8}$ (if it exists) [72], $\mathrm{KIn}_{3} \mathrm{Se}_{5}$ [70], $\mathrm{KInSe}_{2}$ [61, 63, 70], $\mathrm{K}_{4} \mathrm{In}_{2} \mathrm{Se}_{5}$ [70], $\mathrm{K}_{12} \mathrm{In}_{2} \mathrm{Se}_{9}$ [73], $\mathrm{K}_{9} \mathrm{InSe}_{7}$ [73], $\mathrm{K}_{2} \mathrm{Se}, \mathrm{K}_{2} \mathrm{Se}_{2}, \mathrm{~K}_{2} \mathrm{Se}_{4}, \mathrm{~K}_{2} \mathrm{Se}_{5}$, and $\mathrm{K}_{2} \mathrm{Se}_{6}$ [67, 68]. The structures of $\mathrm{KIn}_{3} \mathrm{Se}_{5}, \mathrm{~K}_{4} \mathrm{In}_{2} \mathrm{Se}_{5}, \mathrm{~K}_{2} \mathrm{Se}_{2}, \mathrm{~K}_{2} \mathrm{Se}_{4}, \mathrm{~K}_{2} \mathrm{Se}_{5}$, and $\mathrm{K}_{2} \mathrm{Se}_{6}$ have not been published. Phase diagrams and structural information for the K-In-Se system could help decipher these high temperature peak shifts.

Growth temperature and annealing established different $\mathrm{K}$ chemical potentials, but yielded similar results, so the role of substrate $\mathrm{Na}$ and temperature may be separate from $\mathrm{K}$ chemical potential. Equilibration experiments could assist in determining the specific role of $\mathrm{K}$ chemical potential on phase equilibrium in the $\mathrm{Cu}-\mathrm{K}-\mathrm{In}-\mathrm{Se}$ system, as well as any thermodynamic component to the extent of reaction (1). While chemical reactions have been shown to occur during KF PDTs [1, 5-7, 9, 10, 12-14, 29, 30, 34-38, 40, 41, 45], the specific reactants, products, extents and desirability of the reactions are relatively uncertain. The present work has outlined the stability of $\mathrm{CuInSe}_{2}+\mathrm{KInSe}_{2}$ (relative to CKIS) for various conditions, and contributes to understanding the material chemistry behind the PV performance enhancements/detriments of KF PDTs, guiding more robust process engineering for $\mathrm{K}$ introduction, and identifying probable reactants and products in long-term degradation studies. 


\section{Conclusions}

The effect of temperature on phase formation in the $\mathrm{Cu}-\mathrm{K}$-In-Se material system was studied. Increased substrate $\mathrm{Na}$ composition was previously shown to drive CKIS alloy formation (relative to $\mathrm{CuInSe}_{2}+\mathrm{KInSe}_{2}$ mixed phases) during co-evaporation [35]. For Na-rich SLG substrates, changing growth temperature from $600^{\circ} \mathrm{C}$ to $500^{\circ} \mathrm{C}$ also drove the formation of CKIS alloys, as evidenced by SEM, XRD, and UV-visible spectroscopy. Na-poor Mo substrates clearly exhibited the same effect on changing growth temperature from $500^{\circ} \mathrm{C}$ to $400^{\circ} \mathrm{C}$. CKIS alloy formation was therefore favored, relative to $\mathrm{CuInSe}_{2}+\mathrm{KInSe}_{2}$, at increased substrate $\mathrm{Na}$ and decreased temperature. Films had resistivities, minority carrier lifetimes, and carrier concentrations in line with previous reports $[35,52,53]$. Films grown at $400^{\circ} \mathrm{C}$ and $500^{\circ} \mathrm{C}$ were annealed to $600^{\circ} \mathrm{C}$, and showed $\mathrm{K}$ loss in proportion to initial film $\mathrm{K}$ content (XRF and SIMS). Annealing established increased temperature and decreased $\mathrm{K}$ chemical potential, while also reversing reaction (1) and advancing reaction (2) forward (by SEM, XRD, UV-visible spectroscopy, and HTXRD). Annealing's effect on reaction (1) was in excellent agreement with increased growth temperature results, despite the differences in $\mathrm{K}$ chemical potential for the 2 experiments - evidence that $\mathrm{K}$ chemical potential was not the mechanism by which temperature and substrate $\mathrm{Na}$ affected CKIS alloy formation, although phase diagram studies would be needed to affirm or refute this inference. The $\mathrm{KInSe}_{2}$ lattice exhibited contraction at high temperature that progressed with temperature and time, as well as just time. This could have been a result of $\mathrm{Va}_{\mathrm{K}}$ formation, driven by $\mathrm{K}$ evaporation (e.g. reaction (3)). However, other unexplained HTXRD peak shifts were observed at high temperature, and more structural and phase equilibrium data for K-In-Se will be needed to better understand these transitions. The present study has identified promising strategies for understanding and ultimately engineering $\mathrm{K}$ 
bonding in CIGS to maximize initial and long-term PV performance: Process conditions were used to establish relative CuInSe ${ }_{2}$, CKIS, $\mathrm{KInSe}_{2}$, and $\mathrm{K}_{2} \mathrm{In}_{12} \mathrm{Se}_{19}$ phase amounts. The growth trends may prove useful for predicting the presence or absence of minor phase impurities below typical detection limits-impurities that could dominate PV-relevant electronic properties. Furthermore, the results lay a foundation for identifying the thermodynamic and/or kinetic mechanisms ultimately controlling the formation of each $\mathrm{Cu}-\mathrm{K}-\mathrm{In}$ Se phase, as well as predicting probable degradation routes in reliability studies.

Acknowledgement

The authors thank Stephen Glynn for a key suggestion, Kannan Ramanathan for leadership, Lorelle Mansfield, Carolyn Beall, Karen Bowers, and Stephen Glynn for assistance with experiments, Clay DeHart for contact deposition, Matt Young for SIMS, and Bobby To for SEM. EDS and HTXRD were performed at the Center for Nanophase Materials Sciences at Oak Ridge National Laboratory. The work was supported by the U.S. Department of Energy under contract DE-AC36-08GO28308. 
References

[1] A. Chirilă, P. Reinhard, F. Pianezzi, P. Bloesch, A.R. Uhl, C. Fella, L. Kranz, D. Keller, C. Gretener, H. Hagendorfer, D. Jaeger, R. Erni, S. Nishiwaki, S. Buecheler, A.N. Tiwari, Potassium-induced surface modification of $\mathrm{Cu}(\mathrm{In}, \mathrm{Ga}) \mathrm{Se}_{2}$ thin films for high-efficiency solar cells, Nat Mater 12 (2013) 1107-1111.

[2] T.M. Friedlmeier, P. Jackson, A. Bauer, D. Hariskos, O. Kiowski, R. Wuerz, M. Powalla, Improved Photocurrent in $\mathrm{Cu}(\mathrm{In}, \mathrm{Ga}) \mathrm{Se}_{2}$ Solar Cells: From $20.8 \%$ to $21.7 \%$ Efficiency with $\mathrm{CdS}$ Buffer and 21.0\% Cd-Free, IEEE J. Photovolt. 5 (2015) 1487-1491.

[3] P. Jackson, D. Hariskos, R. Wuerz, O. Kiowski, A. Bauer, T.M. Friedlmeier, M. Powalla, Properties of $\mathrm{Cu}(\mathrm{In}, \mathrm{Ga}) \mathrm{Se}_{2}$ solar cells with new record efficiencies up to $21.7 \%$, Phys. Status Solidi RRL 9 (2015) 28-31.

[4] P. Jackson, D. Hariskos, R. Wuerz, W. Wischmann, M. Powalla, Compositional investigation of potassium doped $\mathrm{Cu}(\mathrm{In}, \mathrm{Ga}) \mathrm{Se}_{2}$ solar cells with efficiencies up to $20.8 \%$, Phys. Status Solidi RRL 8 (2014) 219-222.

[5] A. Laemmle, R. Wuerz, M. Powalla, Efficiency enhancement of $\mathrm{Cu}(\mathrm{In}, \mathrm{Ga}) \mathrm{Se}_{2}$ thin-film solar cells by a post-deposition treatment with potassium fluoride, Phys. Status Solidi RRL 7 (2013) 631-634.

[6] L.M. Mansfield, R. Noufi, C.P. Muzzillo, C. DeHart, K. Bowers, B. To, J.W. Pankow, R.C. Reedy, K. Ramanathan, Enhanced performance in $\mathrm{Cu}(\mathrm{In}, \mathrm{Ga}) \mathrm{Se}_{2}$ solar cells fabricated by the two-step selenization process with a potassium fluoride postdeposition treatment, IEEE J. Photovolt. 4 (2014) 1650-1654.

[7] F. Pianezzi, P. Reinhard, A. Chirilă, B. Bissig, S. Nishiwaki, S. Buecheler, A.N. Tiwari, Unveiling the effects of post-deposition treatment with different alkaline elements on the electronic properties of CIGS thin film solar cells, Phys. Chem. Chem. Phys. 16 (2014) 88438851.

[8] F. Pianezzi, P. Reinhard, A. Chirilă, S. Nishiwaki, B. Bissig, S. Buecheler, A.N. Tiwari, Defect formation in $\mathrm{Cu}(\mathrm{In}, \mathrm{Ga}) \mathrm{Se}_{2}$ thin films due to the presence of potassium during growth by low temperature co-evaporation process, J. Appl. Phys. 114 (2013) 194508-194508.

[9] P. Reinhard, B. Bissig, F. Pianezzi, E. Avancini, H. Hagendorfer, D. Keller, P. Fuchs, M. Döbeli, C. Vigo, P. Crivelli, S. Nishiwaki, S. Buecheler, A.N. Tiwari, Features of KF and NaF Postdeposition Treatments of $\mathrm{Cu}(\mathrm{In}, \mathrm{Ga}) \mathrm{Se}_{2}$ Absorbers for High Efficiency Thin Film Solar Cells, Chem. Mater. 27 (2015) 5755-5764.

[10] J.M. Raguse, C.P. Muzzillo, J.R. Sites, L. Mansfield, Effects of Sodium and Potassium on the Photovoltaic Performance of CIGS Solar Cells, IEEE J. Photovolt. 7 (2017) 303-306. [11] R. Kamada, T. Yagioka, S. Adachi, A. Handa, K.F. Tai, T. Kato, H. Sugimoto, New world record $\mathrm{Cu}(\mathrm{In}, \mathrm{Ga})(\mathrm{Se}, \mathrm{S})_{2}$ thin film solar cell efficiency beyond $22 \%$, in: IEEE Photovolt. Specialists Conf., Portland, OR, 2016, pp. 1287-1291. [12] O. Lundberg, E. Wallin, V. Gusak, S. Södergren, S. Chen, S. Lotfi, F. Chalvet, U. Malm, N. Kaihovirta, P. Mende, G. Jaschke, P. Kratzert, J. Joel, M. Skupinski, P. Lindberg, T. Jarmar, J. Lundberg, J. Mathiasson, L. Stolt, Improved CIGS Modules by KF Post Deposition Treatment and Reduced Cell-to-Module Losses, in: IEEE Photovolt. Specialists Conf., Portland, OR, 2016, pp. 1-4. 
[13] T. Lepetit, Influence of KF post deposition treatment on the polycrystalline $\mathrm{Cu}(\mathrm{In}, \mathrm{Ga}) \mathrm{Se}_{2} / \mathrm{CdS}$ heterojunction formation for photovoltaic application, in: Mater. Sci., Université de Nantes, Nantes, FR, 2015, pp. 132.

[14] I. Khatri, H. Fukai, H. Yamaguchi, M. Sugiyama, T. Nakada, Effect of potassium fluoride post-deposition treatment on $\mathrm{Cu}(\mathrm{In}, \mathrm{Ga}) \mathrm{Se}_{2}$ thin films and solar cells fabricated onto sodalime glass substrates, Sol. Energy Mater. Sol. Cells 155 (2016) 280-287.

[15] A. Laemmle, R. Wuerz, M. Powalla, Investigation of the effect of potassium on $\mathrm{Cu}(\mathrm{In}, \mathrm{Ga}) \mathrm{Se}_{2}$ layers and solar cells, Thin Solid Films 582 (2015) 27-30.

[16] T. Kato, $\mathrm{Cu}(\mathrm{In}, \mathrm{Ga})(\mathrm{Se}, \mathrm{S})_{2}$ solar cell research in Solar Frontier: Progress and current status, Jpn. J. Appl. Phys. 56 (2017) 04CA02.

[17] C.-H. Hsu, W.-H. Ho, S.-Y. Wei, C.-H. Lai, Over 14\% Efficiency of Directly Sputtered $\mathrm{Cu}(\mathrm{In}, \mathrm{Ga}) \mathrm{Se}_{2}$ Absorbers without Postselenization by Post-Treatment of Alkali Metals, Adv. Energy Mat. in press (2017) 1602571.

[18] S.A. Jensen, S. Glynn, A. Kanevce, P. Dippo, J.V. Li, D.H. Levi, D. Kuciauskas, Beneficial effect of post-deposition treatment in high-efficiency $\mathrm{Cu}(\mathrm{In}, \mathrm{Ga}) \mathrm{Se}_{2}$ solar cells through reduced potential fluctuations, J. Appl. Phys. 120 (2016) 063106-063107.

[19] I. Khatri, M. Sugiyama, T. Nakada, Effects of combined additional indium deposition and potassium fluoride post-deposition treatments on $\mathrm{Cu}(\mathrm{In}, \mathrm{Ga}) \mathrm{Se}_{2}$ thin film solar cells, Prog.

Photovoltaics 10.1002/pip.2892 (2017) in press.

[20] J.A. Aguiar, A. Stokes, C.-S. Jiang, T. Aoki, P.G. Kotula, M.K. Patel, B. Gorman, M. AlJassim, Revealing Surface Modifications of Potassium-Fluoride-Treated $\mathrm{Cu}(\mathrm{In}, \mathrm{Ga}) \mathrm{Se}_{2}$ : A Study of Material Structure, Chemistry, and Photovoltaic Performance, Adv. Mater. Interfaces 3 (2016) 1600013.

[21] E. Handick, P. Reinhard, R.G. Wilks, F. Pianezzi, T. Kunze, D. Kreikemeyer-Lorenzo, L. Weinhardt, M. Blum, W. Yang, M. Gorgoi, E. Ikenaga, D. Gerlach, S. Ueda, Y. Yamashita, T. Chikyow, C. Heske, S. Buecheler, A.N. Tiwari, M. Bär, Formation of a K-In-Se surface species by $\mathrm{NaF} / \mathrm{KF}$ post-deposition treatment of $\mathrm{Cu}(\mathrm{In}, \mathrm{Ga}) \mathrm{Se}_{2}$ thin-film solar cell absorbers, ACS Appl. Mater. Interfaces 9 (2017) 3581-3589.

[22] S. Karki, P.K. Paul, G. Rajan, T. Ashrafee, K. Aryal, P. Pradhan, R.W. Collins, A. Rockett, T.J. Grassman, S.A. Ringel, A.R. Arehart, S. Marsillac, In Situ and Ex Situ Investigations of KF Postdeposition Treatment Effects on CIGS Solar Cells, IEEE J. Photovolt. 7 (2017) 665-669. [23] S. Zahedi-Azad, R. Scheer, Quenching interface recombination in wide bandgap $\mathrm{Cu}(\mathrm{In}, \mathrm{Ga}) \mathrm{Se}_{2}$ by potassium treatment, Phys. Status Solidi C in press (2017) 1600203.

[24] M. Mezher, Novel pathways to high-efficiency chalcopyrite photovoltaic devices: A spectroscopic investigation of alternative buffer layers and alkali-treated absorbers, in:

Department of Chemistry and Biochemistry, University of Nevada, Las Vegas, Las Vegas, NV, 2016, pp. 164.

[25] D. Shin, J. Kim, T. Gershon, R. Mankad, M. Hopstaken, S. Guha, B.T. Ahn, B. Shin, Effects of the incorporation of alkali elements on $\mathrm{Cu}(\mathrm{In}, \mathrm{Ga}) \mathrm{Se}_{2}$ thin film solar cells, Sol. Energy Mater. Sol. Cells 157 (2016) 695-702.

[26] NREL, Best Research-Cell Efficiencies, in, NCPV, Golden, CO, 2016.

[27] Press-release, ZSW Sets New World Record for Thin-Film Solar Cells, in, Zentrum für Sonnenenergie- und Wasserstoff-Forschung Baden-Württemberg, Stuttgart, DE, 2016.

[28] D. Hariskos, P. Jackson, W. Hempel, S. Paetel, S. Spiering, R. Menner, W. Wischmann, M. Powalla, Method for a high-rate solution deposition of $\mathrm{Zn}(\mathrm{O}, \mathrm{S})$ buffer layer for high efficiency 
$\mathrm{Cu}(\mathrm{In}, \mathrm{Ga}) \mathrm{Se}_{2}$-based solar cells, in: IEEE Photovolt. Specialists Conf., Portland, OR, 2016, pp. $1-6$.

[29] G.S. Jeong, E.S. Cha, S.H. Moon, B.T. Ahn, Effect of KF Treatment of $\mathrm{Cu}(\mathrm{In}, \mathrm{Ga}) \mathrm{Se}_{2}$ Thin Films on the Photovoltaic Properties of CIGS Solar Cells, Curr. Photovolt. Res. 3 (2015) 65-70. [30] Y.-S. Son, W.M. Kim, J.-K. Park, J.-h. Jeong, KF Post Deposition Treatment Process of $\mathrm{Cu}(\mathrm{In}, \mathrm{Ga}) \mathrm{Se}_{2}$ Thin Film Effect of the Na Element Present in the Solar Cell Performance, Curr. Photovolt. Res. 3 (2015) 130-134.

[31] Z.-K. Yuan, S. Chen, Y. Xie, J.-S. Park, H. Xiang, X.-G. Gong, S.-H. Wei, Na-Diffusion Enhanced p-type Conductivity in $\mathrm{Cu}(\mathrm{In}, \mathrm{Ga}) \mathrm{Se}_{2}$ : A New Mechanism for Efficient Doping in Semiconductors, Adv. Energy Mat. 6 (2016) 1601191.

[32] M.A. Contreras, B. Egaas, P. Dippo, J. Webb, J. Granata, K. Ramanathan, S. Asher, A. Swartzlander, R. Noufi, On the role of $\mathrm{Na}$ and modifications to $\mathrm{Cu}(\mathrm{In}, \mathrm{Ga}) \mathrm{Se}_{2}$ absorber materials using thin-MF ( $\mathrm{M}=\mathrm{Na}, \mathrm{K}, \mathrm{Cs}$ ) precursor layers, in: IEEE Photovolt. Specialists Conf., 1997, pp. 359-362.

[33] C.S. Jiang, B. To, S. Glynn, H. Mahabaduge, T. Barnes, M.M. Al-Jassim, Recent progress in nanoelectrical characterizations of $\mathrm{CdTe}$ and $\mathrm{Cu}(\mathrm{In}, \mathrm{Ga}) \mathrm{Se}_{2}$, in: IEEE Photovolt. Specialists Conf., 2016, pp. 3675-3680.

[34] S. Karki, P. Paul, G. Rajan, T. Ashrafee, K. Aryal, P. Pradhan, R.W. Collins, A.A. Rockett, T.J. Grassman, S.A. Ringel, A.R. Arehart, S. Marsillac, In-situ and Ex-situ Characterizations of CIGS Solar Cells with KF Post Deposition Treatment, in: IEEE Photovolt. Specialists Conf., Portland, OR, 2016, pp. 1-6.

[35] C.P. Muzzillo, H.M. Tong, T.J. Anderson, The effect of Na on Cu-K-In-Se thin film growth, https://arxiv.org/abs/1703.06365 submitted (2017).

[36] E. Handick, P. Reinhard, R.G. Wilks, F. Pianezzi, R. Félix, M. Gorgoi, T. Kunze, S.

Buecheler, A.N. Tiwari, M. Bär, NaF/KF Post-Deposition Treatments and their Influence on the Structure of $\mathrm{Cu}(\mathrm{In}, \mathrm{Ga}) \mathrm{Se}_{2}$ Absorber Surfaces, in: IEEE Photovolt. Specialists Conf., Portland, OR, 2016, pp. 1-5.

[37] T. Lepetit, S. Harel, L. Arzel, G. Ouvrard, N. Barreau, Co-evaporated $\mathrm{KInSe}_{2}$ : a fast alternative to KF post-deposition treatment in high efficiency $\mathrm{Cu}(\mathrm{In}, \mathrm{Ga}) \mathrm{Se}_{2}$ thin film solar cells, in: IEEE Photovolt. Specialists Conf., Portland, OR, 2016, pp. 1-4.

[38] E. Handick, P. Reinhard, J.-H. Alsmeier, L. Köhler, F. Pianezzi, S. Krause, M. Gorgoi, E. Ikenaga, N. Koch, R.G. Wilks, S. Buecheler, A.N. Tiwari, M. Baer, Potassium post-deposition treatment-induced band gap widening at $\mathrm{Cu}(\mathrm{In}, \mathrm{Ga}) \mathrm{Se}_{2}$ surfaces - Reason for performance leap?, ACS Appl. Mater. Interfaces 7 (2015) 27414-27420.

[39] H. Elanzeery, F. Babbe, M. Melchiorre, A. Zelenina, S. Siebentritt, Potassium Fluoride Ex Situ Treatment on Both $\mathrm{Cu}$-Rich and $\mathrm{Cu}-\mathrm{Poor} \mathrm{CuInSe} \mathrm{S}_{2}$ Thin Film Solar Cells, IEEE J. Photovolt. 7 (2017) 684-689.

[40] B. Umsur, W. Calvet, A. Steigert, I. Lauermann, M. Gorgoi, K. Prietzel, D. Greiner, C.A. Kaufmann, T. Unold, M. Lux-Steiner, Investigation of the potassium fluoride post deposition treatment on the CIGSe/CdS interface using hard x-ray photoemission spectroscopy - a comparative study, Phys. Chem. Chem. Phys. 18 (2016) 14129-14138. [41] P. Pistor, D. Greiner, C.A. Kaufmann, S. Brunken, M. Gorgoi, A. Steigert, W. Calvet, I. Lauermann, R. Klenk, T. Unold, M.-C. Lux-Steiner, Experimental indication for band gap widening of chalcopyrite solar cell absorbers after potassium fluoride treatment, Appl. Phys. Lett. 105 (2014) 063901-063904. 
[42] T. Maeda, A. Kawabata, T. Wada, First-principles study on alkali-metal effect of Li, Na, and $\mathrm{K}$ in $\mathrm{CuInSe}_{2}$ and $\mathrm{CuGaSe}_{2}$, Jpn. J. Appl. Phys. 54 (2015) 08KC20.

[43] T.M. Friedlmeier, P. Jackson, D. Kreikemeyer-Lorenzo, D. Hauschild, O. Kiowski, D. Hariskos, L. Weinhardt, C. Heske, M. Powalla, A Closer Look at Initial CdS Growth on HighEfficiency $\mathrm{Cu}(\mathrm{In}, \mathrm{Ga}) \mathrm{Se}_{2}$ Absorbers Using Surface-Sensitive Methods, in: IEEE Photovolt. Specialists Conf., Portland, OR, 2016, pp. 1-5.

[44] T. Lepetit, S. Harel, L. Arzel, G. Ouvrard, N. Barreau, Coevaporated KInSe 2 : A Fast Alternative to KF Postdeposition Treatment in High-Efficiency $\mathrm{Cu}(\mathrm{In}, \mathrm{Ga}) \mathrm{Se}_{2}$ Thin Film Solar Cells, IEEE J. Photovolt. PP (2016) 1-5.

[45] P. Reinhard, B. Bissig, F. Pianezzi, H. Hagendorfer, G. Sozzi, R. Menozzi, C. Gretener, S. Nishiwaki, S. Buecheler, A.N. Tiwari, Alkali-Templated Surface Nanopatterning of Chalcogenide Thin Films: A Novel Approach Toward Solar Cells with Enhanced Efficiency, Nano Lett. 15 (2015) 3334-3340.

[46] Y. Zhang, R.E. Bartolo, S.J. Kwon, M. Dagenais, High Short-Circuit Current Density in CIS Solar Cells by a Simple Two-Step Selenization Process With a KF Postdeposition Treatment, IEEE J. Photovolt. 7 (2016) 676-683.

[47] R. Wuerz, A. Eicke, F. Kessler, S. Paetel, S. Efimenko, C. Schlegel, CIGS thin-film solar cells and modules on enamelled steel substrates, Sol. Energy Mater. Sol. Cells 100 (2012) 132137.

[48] D. Colombara, U. Berner, A. Ciccioli, J.C. Malaquias, T. Bertram, A. Crossay, M. Schöneich, H.J. Meadows, D. Regesch, S. Delsante, G. Gigli, N. Valle, J. Guillot, B. El Adib, P. Grysan, P.J. Dale, Deliberate and Accidental Gas-Phase Alkali Doping of Chalcogenide Semiconductors: $\mathrm{Cu}(\mathrm{In}, \mathrm{Ga}) \mathrm{Se}_{2}$, Sci. Rep. 7 (2017) 43266.

[49] N. Barreau, P. Zabierowski, L. Arzel, M. Igalson, K. Macielak, A. Urbaniak, T. Lepetit, T. Painchaud, A. Dönmez, J. Kessler, Influence of post-deposition selenium supply on $\mathrm{Cu}(\mathrm{In}, \mathrm{Ga}) \mathrm{Se}_{2}$-based solar cell properties, Thin Solid Films 582 (2015) 43-46. [50] Y.M. Shin, C.S. Lee, D.H. Shin, H.S. Kwon, B.G. Park, B.T. Ahn, Surface modification of CIGS film by annealing and its effect on the band structure and photovoltaic properties of CIGS solar cells, Curr. Appl Phys. 15 (2015) 18-24.

[51] M. Theelen, V. Hans, N. Barreau, H. Steijvers, Z. Vroon, M. Zeman, The impact of alkali elements on the degradation of CIGS solar cells, Prog. Photovoltaics 23 (2015) 537-545. [52] C.P. Muzzillo, Chalcopyrites for Solar Cells: Chemical Vapor Deposition, Selenization, and Alloying, in: Chemical Engineering, University of Florida, Gainesville, FL, 2015, pp. 458. [53] C.P. Muzzillo, L.M. Mansfield, K. Ramanathan, T.J. Anderson, Properties of $\mathrm{Cu}_{1-\mathrm{x}} \mathrm{K}_{\mathrm{x}} \mathrm{InSe}_{2}$ alloys, J. Mat. Sci. 51 (2016) 6812-6823.

[54] C.P. Muzzillo, J.V. Li, L.M. Mansfield, K. Ramanathan, T.J. Anderson, Surface and bulk effects of $\mathrm{K}$ in highly efficient $\mathrm{Cu}_{1-\mathrm{x}} \mathrm{K}_{\mathrm{x}} \mathrm{InSe} \mathrm{Se}_{2}$ solar cells, https://arxiv.org/abs/1704.01560 submitted (2017).

[55] C.P. Muzzillo, T.J. Anderson, Surface and bulk effects of $\mathrm{K}$ in $\mathrm{Cu}_{1-\mathrm{x}} \mathrm{K}_{\mathrm{x}} \mathrm{In}_{1-\mathrm{y}} \mathrm{Ga}_{\mathrm{y}} \mathrm{Se}_{2}$ solar cells, https://arxiv.org/abs/1704.01593 submitted (2017).

[56] C.P. Muzzillo, L.M. Mansfield, C. Dehart, K. Bowers, R.C. Reedy, B. To, R. Noufi, K. Ramanathan, T.J. Anderson, The effect of Ga content on the selenization of co-evaporated $\mathrm{CuGa} / \mathrm{In}$ films and their photovoltaic performance, in: IEEE Photovolt. Specialists Conf., Denver, CO, 2014, pp. 1649-1654. 
[57] C.P. Muzzillo, L.M. Mansfield, C. DeHart, K. Bowers, R.C. Reedy, B. To, K. Ramanathan, T.J. Anderson, Differences between $\mathrm{CuGa} / \mathrm{In}$ and $\mathrm{Cu} / \mathrm{Ga} / \mathrm{In}$ films for selenization, in: IEEE Photovolt. Specialists Conf., New Orleans, LA, 2015, pp. 1-6.

[58] S. Ishizuka, A. Yamada, M.M. Islam, H. Shibata, P. Fons, T. Sakurai, K. Akimoto, S. Niki, Na-induced variations in the structural, optical, and electrical properties of $\mathrm{Cu}(\mathrm{In}, \mathrm{Ga}) \mathrm{Se}_{2}$ thin films, J. Appl. Phys. 106 (2009) 034908-034906.

[59] O. Lundberg, J. Lu, A. Rockett, M. Edoff, L. Stolt, Diffusion of indium and gallium in $\mathrm{Cu}(\mathrm{In}, \mathrm{Ga}) \mathrm{Se}_{2}$ thin film solar cells, J. Phys. Chem. Solids 64 (2003) 1499-1504.

[60] M. Schlosser, C. Reiner, H.-J. Deiseroth, L. Kienle, $\mathrm{K}_{2} \mathrm{In}_{12} \mathrm{Se}_{19}$, a Complex New Structure Type Based on Icosahedral Units of Se ${ }^{2-}$, Eur. J. Inorg. Chem. 2001 (2001) 2241-2247. [61] P. Wang, X.-Y. Huang, Y.-L. Liu, Y.-G. Wei, J. Li, H.-Y. Guo, Solid state synthesis at intermediate temperature and structural characterization of $\mathrm{KInSe}_{2}$, Acta Chim. Sinica 58 (2000) 1005-1008.

[62] I.L. Repins, B. Egaas, L.M. Mansfield, M.A. Contreras, C.P. Muzzillo, C. Beall, S. Glynn, J. Carapella, D. Kuciauskas, Fiber-fed time-resolved photoluminescence for reduced process feedback time on thin-film photovoltaics, Rev. Sci. Instrum. 86 (2015) 013907-013907.

[63] H.-W. Ma, Guo, M.-S. Wang, GuoZhou, S.-H. Lin, Z.-C. Dong, J.-S. Huang, $\mathrm{K}_{2} \mathrm{MM}_{3}{ }_{3} \mathrm{Se}_{6}$ $\left(\mathrm{M}=\mathrm{Cu}, \mathrm{Ag} ; \mathrm{M}^{`}=\mathrm{Ga}, \mathrm{In}\right)$, A New Series of Metal Chalcogenides with Chain-Sublayer-Chain Slabs: ${ }_{\infty}^{1}\left[\mathrm{M}^{`} \mathrm{Se}_{4}\right]-{ }_{\infty}{ }^{2}\left[\left(\mathrm{MSe}_{4}\right)\left(\mathrm{M}^{`} \mathrm{Se}_{4}\right)\right]-{ }_{\infty}^{1}\left[\mathrm{M}^{`} \mathrm{Se}_{4}\right]$, Inorg. Chem. 42 (2003) 1366-1370. [64] G.-H. Wang, H.-Y. Guo, Solid-state synthesis of $\mathrm{K}_{2} \mathrm{CuIn}_{3} \mathrm{Se}_{6}$ and its crystal structure and characterization, Journal of Beijing University of Chemical Technology 31 (2004) 73-77. [65] J.W. Orton, M.J. Powell, The Hall effect in polycrystalline and powdered semiconductors, Rep. Prog. Phys. 43 (1980) 1263-1307.

[66] L. Kienle, A. Simon, Microdomains and Diffuse Scattering in $\mathrm{K}_{2} \mathrm{In}_{12} \mathrm{Se}_{19}$, J. Solid State Chem. 161 (2001) 385-395.

[67] W. Klemm, H. Sodomann, P. Langmesser, Beiträge Zur Kenntnis der Alkalimetallchalkogenide, Z. Anorg. Allg. Chem. 241 (1939) 281-304.

[68] J. Sangster, A.D. Pelton, The K-Se (Potassium-Selenium) System, J. Phase Equilib. 18 (1997) 177-180.

[69] C.P. Muzzillo, J.D. Poplawsky, H.M. Tong, T.J. Anderson, Characterization of K in grain interiors, grain boundaries, and at the buffer interface in highly efficient $\mathrm{Cu}_{1-\mathrm{x}} \mathrm{K}_{\mathrm{x}} \mathrm{InSe}_{2}$ solar cells, submitted (2017).

[70] Z.Z. Kish, V.B. Lazarev, E.Y. Peresh, E.E. Semrad, Compounds in $\mathrm{In}_{2} \mathrm{Se}_{3}-\mathrm{K}_{2} \mathrm{Se}$, Neorg. Mater. 24 (1988) 1602-1605.

[71] J.-B. Li, M.-C. Record, J.-C. Tedenac, A thermodynamic assessment of the In-Se system, Z. Metallk. 94 (2003) 381-389.

[72] H.J. Deiseroth, Splitpositionen für Alkalimetallkationen in den Thioindaten $\mathrm{MIn}_{5} \mathrm{~S}_{8}(\mathrm{M}=\mathrm{K}$, Rb, Cs)?, Z. Kristallogr. Cryst. Mater. 177 (1986) 307-314.

[73] J. Heine, S. Dehnen, Synthesis and Characterization of the First Salts of the ortho-

Selenidoindate Anion [InSe 4$]^{5-}$, Z. Anorg. Allg. Chem. 634 (2008) 2303-2308. 